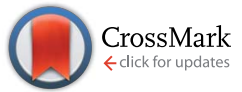

Cite this: RSC Adv., 2016, 6, 76600

\title{
Benzimidazole based Pt(II) complexes with better normal cell viability than cisplatin: synthesis, substitution behavior, cytotoxicity, DNA binding and DFT study $\dagger$
}

\begin{abstract}
Ishani Mitra, ${ }^{a}$ Subhajit Mukherjee, ${ }^{a}$ Venkata P. Reddy B., ${ }^{a}$ Subrata Dasgupta, ${ }^{a}$ Jagadeesh C. Bose $K^{b}$ Sandip Mukherjee, ${ }^{c}$ Wolfgang Linert ${ }^{d}$ and Sankar Ch. Moi ${ }^{\star a}$

cis-[Pt(ambim) $\left.\mathrm{Cl}_{2}\right] 1$ (where, ambim = 2-aminomethylbenzimidazole) has been synthesized and characterized by spectroscopic methods. Reaction kinetics between the hydrolyzed product, cis$\left[\mathrm{Pt}\left(\text { ambim) }\left(\mathrm{H}_{2} \mathrm{O}\right)_{2}\right]^{2+} 2\right.$ with DL-penicillamine (DL-pen) and glutathione (GSH) have been studied spectrophotometrically in aqueous medium. At pH 4.0, the interactions of 2 with the ligands show two distinct consecutive steps. The association equilibrium constant $\left(K_{E}\right)$ for the outer sphere complex formation and rate constants for both the steps have been evaluated. Activation parameters $\left(\Delta H^{\ddagger}\right.$ and $\left.\Delta S^{*}\right)$ were evaluated using the Eyring equation and an associative mechanism is proposed for both the reactions. Computational studies using Density Functional Theory (DFT) were carried out to investigate the electronic structures of the complexes. To study the nature of the electronic transitions in complex 1, time dependent DFT was performed. The DNA binding properties of the complexes 2-4 were evaluated by spectroscopic titration, fluorescence indicator displacement experiments and electrophoresis measurements. The complexes effectively bind to calf-thymus DNA via different binding modes with intrinsic binding constants $\left(K_{\mathrm{b}}\right)$ in the range of $2.22 \times 10^{4}$ to $4.76 \times 10^{4} \mathrm{M}^{-1}$ which was supported by molecular docking studies. The antiproliferative properties of $2-4$ were probed in vitro against human cervical cancer, non-small cell lung carcinoma and hepatocellular liver carcinoma cell lines and 2 was found to be most effective in growth inhibition in all the cell lines. Remarkably, the complexes also generate lower levels of reactive oxygen species (ROS) than cisplatin and have almost no adverse effects on normal cells.
\end{abstract}

Received 12th July 2016

Accepted 3rd August 2016

DOI: $10.1039 / c 6 r a 17788 c$

www.rsc.org/advances

\section{Introduction}

Since its arrival in the clinic in 1978 , cisplatin ${ }^{1}$ has played a vital role in cancer chemotherapy, either unaided or in combination with other chemotherapeutics. ${ }^{2}$ The activity of cisplatin arises from its ability to bind to DNA via covalent cross-links, predominantly by a 1,2 intrastrand crosslink between the $\left[\mathrm{Pt}\left(\mathrm{NH}_{3}\right)_{2}\right]^{2+}$ unit and two adjacent guanine bases of DNA. ${ }^{1}$ Despite its widespread use, the therapeutic success of cisplatin is marred by several adverse effects, and both inherent and acquired resistances limit its efficacy. ${ }^{3-6}$ Moreover, recent

${ }^{a}$ Department of Chemistry, National Institute of Technology, Durgapur-713209, W.B., India.E-mail: sankarmoi67@yahoo.com

${ }^{b}$ Department of Bio-Technology, National Institute of Technology, Durgapur-713209, W. B., India

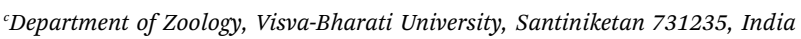
${ }^{d}$ Institute of Applied Synthetic Chemistry, Vienna University of Technology, Getreidemarkt, 9/163-AC, 1060, Vienna, Austria

$\dagger$ Electronic supplementary information (ESI) available. See DOI: $10.1039 / \mathrm{c} 6 \mathrm{ra} 17788 \mathrm{c}$ studies have shown that its exposure in several tissues leads to oxidative damage in vivo, indicating that oxidative stress plays a role in the pathogenesis of cisplatin-induced dose limiting toxicities. ${ }^{7}$ Unfortunately, its successors, carboplatin and oxaliplatin have not yet demonstrated significant advantages over cisplatin and hence there is an increasingly growing interest in the development of alternative strategies to deliver platinum drugs with enhanced efficacy and cellular uptake and reduced drug resistance. ${ }^{8-15}$

Non-covalent DNA recognition might be a powerful way for metal complexes to exert an anticancer effect through unique molecular actions. Many platinum complexes bearing $\pi$ conjugated heterocyclic ligands have been developed and their anti-cancer properties investigated..$^{16-18}$ The planar aromatic ligand allows these complexes to intercalate non-covalently between the base pairs of DNA. Additionally, inclusion of sterically demanding ligands has also yielded cytotoxic metal complexes which act as DNA groove binders. ${ }^{19-21}$ With the aim of exploring the ability of new metal complexes as intercalators or DNA groove binders, we have prepared the platinum(II) 
complex, $\left[\mathrm{Pt}(\mathrm{ambim}) \mathrm{Cl}_{2}\right], \quad \mathbf{1}$, its diaqua analogue, $\left[\mathrm{Pt}(\operatorname{ambim})\left(\mathrm{H}_{2} \mathrm{O}\right)_{2}\right]^{2+}, 2$ and the substituted complexes [Pt(ambim)(DL-pen) $]^{+}, 3$ and $[\mathrm{Pt}(\operatorname{ambim})(\mathrm{GSH})], \mathbf{4}$, where ambim $=2$ aminomethylbenzimidazole. The chemistry and pharmacology of benzimidazoles has been of immense relevance to medicinal chemistry as its derivatives possess various biological activities. ${ }^{22-24}$ Ambim has in fact been utilized to develop innovative compounds for the treatment of cancer. ${ }^{25,26}$ In this work, cytotoxicity of the carrier ligand ambim and the synthesized Pt(II) complexes were evaluated on different tumor cell lines in comparison to cisplatin. To assess the effect on normal cells upon treatment with the complexes and cisplatin, assays for viability and reactive oxygen species (ROS) generated were also performed. Moreover, DNA binding properties of the complexes have been reported along with docking studies to rationalize the interactions.

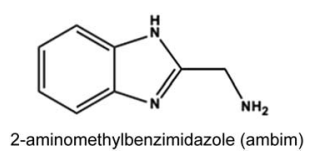

DNA platination is commonly accepted as the ultimate event in the mechanism of action of platinum anticancer drugs. ${ }^{27}$ However, already in the blood, where the Pt drug is administered by injection or infusion, several sulfur-donor ligands are available for kinetic and thermodynamic competition. ${ }^{28}$ It is hypothesized that the platinum temporarily binds to the $\mathrm{S}$ containing bio-molecules in the cell, forming an intermediate which acts as a platinum reservoir, ${ }^{28-30}$ before finally interacting with guanine-N7 of DNA. The Pt-S interactions are believed to be kinetically preferred but the Pt-DNA adducts are thermodynamically more stable under physiological conditions. In this paper, kinetic measurements were carried out to study the substitution reactions of complex 2 with biologically relevant nucleophiles. DL-Penicillamine ( $\beta, \beta^{\prime}$-dimethyl cysteine), is a degradation product of $\beta$-lactum antibiotic, penicillin, and a S-containing bioactive ligand, while glutathione (g-Glu-CysHGly, GSH) is the most prevalent intracellular thiol with concentrations up to $10 \mathrm{mM}$ and is the most abundant low molecular weight peptide. The study of the chemical transformations of cytotoxic Pt(II) complexes with sulfur containing biologically relevant nucleophiles provides a fundamental basis for understanding toxicity and development of resistance in biological systems and hence, is of special concern for pharmaceutical and biomedical research.

\section{Experimental}

\section{Reagents}

All chemicals used for the kinetic and bio-activity study were of highest purity as available. The starting compounds $\mathrm{K}_{2} \mathrm{PtCl}_{4}$ (99\%), 2-aminomethylbenzimidazole (ambim) (98\%), DL-penicillamine (97\%) and glutathione (98\%) were purchased from Sigma Aldrich. $\mathrm{AgClO}_{4}$ (97\%), $\mathrm{AgNO}_{3}$ (99\%), $\mathrm{K}_{2} \mathrm{HPO}_{4}$ and $\mathrm{NaClO}_{4}$ were purchased from Merck. All these reagents were used without further purification. For kinetic purpose, double distilled water was used to prepare all kinds of solutions and molecular biology grade water was used for bioactivity study. All solvents used were of analytical grade. Cisplatin (Cis-gland) was purchased from Gland Pharma Limited. Dulbecco's modified Eagle medium (DMEM), phosphate-buffered saline (PBS) and fetal bovine serum (FBS) were purchased from Hi-Media. Agarose, nitrotetrazolium blue chloride (NBT), Tris-borateEDTA (TBE) and ethidium bromide (EtBr) were purchased from Sigma-Aldrich and used in gel electrophoresis experiment.

\section{Physical measurements}

Elemental analysis of the complexes was carried out on a Perkin-Elmer 2400 series-II CHNS/O Analyser. The pH measurements were done with the help of a Eutech digital $\mathrm{pH}$ meter $(\mathrm{pH}$ Tutor) with accuracy of $\pm 0.01 \mathrm{U}$, calibrated with a standard phosphate buffer solution $\left(\mathrm{KH}_{2} \mathrm{PO}_{4} / \mathrm{Na}_{2} \mathrm{HPO}_{4}\right)$. Fourier transform infrared (FTIR) spectra of the complexes were recorded on a Nicolet-iS-10 spectrometer ( $\mathrm{KBr}$ disk, in the range of 4000-400 $\mathrm{cm}^{-1}$ ). The kinetic measurements and absorption titrations were performed with a Shimadzu UV 1800 spectrophotometer attached to a thermoelectric cell temperature controller (Model TCC-100, accuracy $\pm 0.1{ }^{\circ} \mathrm{C}$ ). Emission spectra were recorded using a HITACHI F-2500 Fluorescence spectrophotometer. ${ }^{1} \mathrm{H}$ NMR spectra were recorded with a Bruker Avance-400 (400 $\mathrm{MHz}$ ) spectrometer using $\mathrm{D}_{2} \mathrm{O}$ or DMSO- $\mathrm{d}_{6}$ as solvent. ${ }^{13} \mathrm{C}$ NMR was recorded on a Bruker Avance-200 (200 MHz). Waters Q-TOF Micro YA263 Mass spectrometer was used to record ESI-MS in water. The $\mathrm{p} K_{\mathrm{a}}$ values of the complex 2 were determined by Metrohm 888 Titrando titro-processor. Stat Fax ${ }^{\mathrm{TM}}{ }^{\circledR} 2100$ Microplate (USA) Enzyme-linked immunosorbent assay (ELISA) plate reader was used for MTT assay. The agarose gel electrophoresis was carried out in Bio-Rad Mini-Sub Cell GT System. The gel picture was taken with Imager Gel Doc ${ }^{\mathrm{TM}}$ EZ. Ziess Axio Observer. Z1 inverted microscope was used to capture the cell images with $100 \times$ magnification.

\section{Syntheses of complexes}

[Pt(ambim) $\left.\mathbf{C l}_{2}\right](\mathbf{1}) .0 .25 \mathrm{~g}(0.6 \mathrm{mmol})$ of $\mathrm{K}_{2} \mathrm{PtCl}_{4}$ was dissolved in minimum amount of water and the solution was heated to $50-60{ }^{\circ} \mathrm{C}$. The ligand, available in dihydrochloride form was neutralised with requisite amount of $\mathrm{NaHCO}_{3}$ for optimum yield. The resulting solution was added dropwise into the $\mathrm{K}_{2} \mathrm{PtCl}_{4}$ solution. The reaction mixture was stirred overnight at $50{ }^{\circ} \mathrm{C}$. Gradually, a grey precipitate of $\mathbf{1}$ appeared and the solution became colourless due to completion of the reaction. The precipitate was filtered off and washed with water, acetone and diethyl ether. The product was dried in a vacuum desiccator and the dry weight was found to be $0.221 \mathrm{~g}$ ( $0.535 \mathrm{mmol}$; yield $89 \%)$.

Elemental analysis of complex $1\left(\mathrm{C}_{8} \mathrm{H}_{9} \mathrm{~N}_{3} \mathrm{Cl}_{2} \mathrm{Pt}\right)$ gave; $\mathrm{C}=$ $23.10 \%$ (23.24); $\mathrm{H}=2.38 \%$ (2.20) and $\mathrm{N}=9.84 \%$ (10.17) where the numbers in parentheses were calculated from the chemical formula.

Electronic absorption spectrum of 1 in DMF, $\left(\lambda_{\max } / \mathrm{nm}\right)(\varepsilon /$ $\mathrm{M}^{-1} \mathrm{~cm}^{-1}$ ): 282 (5757). Selected IR frequencies ( $\mathrm{KBr}$ disk, $\left.\mathrm{cm}^{-1}\right)$ : 3570(m), 3488(br), 3235-3200(br), 3132(m), 3081(ms), 
2964(m), 2927(w), 2788(br), 1620(s), 1578(s), 1477(s), 1454(s), 1417(s), 1385(s), 1284(s), 1154(br), 1002(s) and 740(s) (ESI Fig. S1 $\dagger$ ). ${ }^{1} \mathrm{H}$ NMR (200 MHz, DMSO-d6) of complex $1(\delta$ in ppm and $J$ in $\mathrm{Hz}): \delta 13.79\left(\mathrm{~s}, 1 \mathrm{H}^{\mathrm{d}}\right), \delta 8.54\left(\mathrm{~d}, J=6.0,1 \mathrm{H}^{\mathrm{k}}\right) \delta 7.58(\mathrm{~d}, J=$ 8.0, $\left.1 \mathrm{H}^{\mathrm{f}}\right), \delta 7.46-7.20\left(\mathrm{~m}, 2 \mathrm{H}^{\mathrm{g}, \mathrm{h}}\right), \delta 6.12\left(\mathrm{brt}, 2 \mathrm{H}^{\mathrm{a}}\right), \delta 4.04(\mathrm{t}, J=$ $6.0,2 \mathrm{H}^{\mathrm{b}}$ ) and $\delta 3.38$ (water in DMSO) (ESI Fig. $\mathrm{S} 2 \dagger$ ). ${ }^{13} \mathrm{C} \mathrm{NMR}$ (200 MHz, DMSO-d6) of complex 1 ( $\delta$ in ppm) (ESI Fig. S3†): $\mathrm{C}^{\mathrm{c}}$ (162.75), $\mathrm{C}^{\mathrm{l}}$ (139.30), $\mathrm{C}^{\mathrm{e}}(138.45), \mathrm{C}^{\mathrm{g}}(123.64), \mathrm{C}^{\mathrm{h}}(122.71), \mathrm{C}^{\mathrm{k}}$ (117.59), $\mathrm{C}^{\mathrm{f}}$ (117.38), $\mathrm{C}^{\mathrm{b}}(39.46, \mathrm{~m})$.

$\left[\mathbf{P t}(\mathbf{a m b i m})\left(\mathrm{OH}_{2}\right)_{2}\right]\left(\mathbf{C l O}_{4}\right)_{2} \quad$ (2). The diaqua complex, $\left[\mathrm{Pt}(\operatorname{ambim})\left(\mathrm{OH}_{2}\right)_{2}\right]\left(\mathrm{ClO}_{4}\right)_{2}, 2$ was prepared in solution by the method of Hay and Basak. ${ }^{31}$ The chloro complex 1 (0.15 g; 0.36 $\mathrm{mmol}$ ) was converted into the diaqua complex 2 (Fig. 1) in solution by adding two equivalents of $\mathrm{AgClO}_{4}$. Great care was taken to remove $\mathrm{Ag}^{+}$ions. To ensure the complete removal of $\mathrm{Ag}^{+}$ion from the solution a slightly less amount of $\mathrm{AgClO}_{4}$ $(0.1451 \mathrm{~g} ; 0.70 \mathrm{mmol})$ was taken than the calculated amount (0.1493 $\mathrm{g} ; 0.72 \mathrm{mmol}$ ) for complete utilization of $\mathrm{Ag}^{+}$to remove the chlorides from 2. It was kept overnight and the $\mathrm{AgCl}$ precipitate was removed by filtration through a membrane filter (pore size $0.05 \mu \mathrm{m}$ ) to give a dark yellowish-brown solution. The slight amount of chloro complex, remained unchanged was removed along with the $\mathrm{AgCl}$ precipitate. The concentration of complex 2 solution was calculated on the basis of the consumed amount of $\mathrm{AgClO}_{4}$. The pH of the complex 2 solution was adjusted at 3.0 to prevent dimerisation and freshly prepared dilute solutions of the same were used for kinetic measurements. Another aliquot of 2 was prepared from 1 , as $\mathrm{NO}_{3}{ }^{-}$salt [Pt(ambim) $\left.\left(\mathrm{H}_{2} \mathrm{O}\right)_{2}\right]\left(\mathrm{NO}_{3}\right)_{2}$ using $\mathrm{AgNO}_{3}$ solution for hydrolysis (same method as $\mathrm{AgClO}_{4}$ ) for the purpose of bioactivity studies.

Elemental analysis of complex $2\left(\mathrm{C}_{8} \mathrm{H}_{13} \mathrm{~N}_{3} \mathrm{O}_{10} \mathrm{Cl}_{2} \mathrm{Pt}\right)$ gave; $\mathrm{C}=$ $16.24 \%$ (16.65); $\mathrm{H}=2.22 \%$ (2.27) and $\mathrm{N}=7.35 \%$ (7.28) where the numbers in parentheses were calculated from the chemical formula. Electronic absorption spectrum of 2 in water, $\left(\lambda_{\max } /\right.$ $\mathrm{nm})\left(\varepsilon / \mathbf{M}^{-1} \mathrm{~cm}^{-1}\right): 271$ (5946). Selected IR frequencies (KBr disk, $\left.\mathrm{cm}^{-1}\right)$ : 3629(m), 3424(br), 3130(m), 2923(w), 1636(m), 1596(m), 1559(m), 1545(m), 1477(s), 1457(m), 1401(s), 1282(m), 1085(s), 939(m), 745(m), 625(s) and 443(m) (ESI Fig. S4†). ${ }^{1} \mathrm{H}$ NMR (400 MHz, DMSO-d6) of complex 2 ( $\delta$ in ppm and $J$ in $\mathrm{Hz}$ ): $\delta 8.03$ (d, $J$ $\left.=6.4,1 \mathrm{H}^{\mathrm{k}}\right) \delta 7.92\left(\mathrm{~d}, J=3.6,1 \mathrm{H}^{\mathrm{f}}\right), \delta 7.41-7.38\left(\mathrm{~m}, 2 \mathrm{H}^{\mathrm{g}, \mathrm{h}}\right), \delta 6.32$ (brs, $2 \mathrm{H}^{\mathrm{a}}$ ), $\delta 4.03\left(\mathrm{~s}, 2 \mathrm{H}^{\mathrm{b}}\right.$ ), $\delta 3.69$ (coordinated water) and $\delta 2.50$ (solvent peak) (ESI Fig. S5†).

$[\text { Pt(ambim)(DL-pen) }]^{+}$(3) and [Pt(ambim)(GSH)] (4). Job's method of continuous variation was carried out to confirm the metal : ligand ( $\mathrm{M}: \mathrm{L})$ ratio for the reaction between complex 2 with the ligands at $\mathrm{pH} 4.0$. Both were mixed according to their probable ratios, like $1: 1,1: 2,2: 1$ etc. and heated to near about $50{ }^{\circ} \mathrm{C}$ for few hours and absorbances were measured till a constant maximum was reached. A bell shaped curve was obtained for both DL-pen and GSH when absorbance $v s .[\mathrm{M}] /[\mathrm{M}]$ $+[\mathrm{L}]$ was plotted (ESI Fig. S6 and S7 $\dagger$ ) and the $\mathrm{M}: \mathrm{L}$ ratio was found to be 1:1 which indicates that both act as bidentate ligands. The development of a characteristic peak in the product complexes 3 and 4 at 265 and $273 \mathrm{~nm}$ respectively was monitored as a function of time at different fixed temperatures (ESI Fig. S8 and S9†). Complex 2 and the ligands were mixed in
1 : 1 molar ratio at $\mathrm{pH} 4.0$ in accordance with Job's result to obtain solid products by slow evaporation.

Elemental analysis of complex $3\left(\mathrm{C}_{13} \mathrm{H}_{19} \mathrm{~N}_{4} \mathrm{O}_{6} \mathrm{ClSPt}\right)$ gave; $\mathrm{C}$ $=26.22 \%$ (26.47); $\mathrm{H}=3.21 \%$ (3.25) and $\mathrm{N}=9.14 \%$ (9.50) where the numbers in parentheses were calculated from the chemical formula. Electronic absorption spectrum of 3 in water, $\lambda_{\max } / \mathrm{nm}$ $\left(\varepsilon / \mathrm{M}^{-1} \mathrm{~cm}^{-1}\right)$ : 265 (3552). Selected IR frequencies (KBr disk, $\mathrm{cm}^{-1}$ ): 3448(br), 3121(sh), 2967(w), 2925(w), 1640(s), 1458(m), 1345(m), 1088(s), 940(w), 741(m), 626(s), and 473(s) (ESI Fig. S10 $)$. ${ }^{1} \mathrm{H}$ NMR (400 MHz, $\delta$ in ppm DMSO-d6) data for complex 3: $\delta 8.51\left(\mathrm{~d}, J=6.4 \mathrm{~Hz}, 1 \mathrm{H}^{\mathrm{k}}\right), \delta 8.44\left(\mathrm{~d}, J=6.4 \mathrm{~Hz}, 1 \mathrm{H}^{\mathrm{f}}\right)$, $\delta 8.27-8.16\left(\mathrm{~m}, 2 \mathrm{H}^{\mathrm{g}, \mathrm{h}}\right), \delta 6.56\left(\mathrm{brt}, 2 \mathrm{H}^{\mathrm{a}}\right), \delta 6.10\left(\mathrm{brs}, 3 \mathrm{H}^{\mathrm{z}}\right), \delta 4.09$ $\left(\mathrm{d}, J=6.0 \mathrm{~Hz}, 2 \mathrm{H}^{\mathrm{b}}\right), \delta 3.48\left(\mathrm{~s}, 1 \mathrm{H}^{\mathrm{w}}\right), \delta 3.44$ (water in DMSO), $\delta 2.53$ (solvent peak), $\delta 2.35\left(\mathrm{~s}, 3 \mathrm{H}^{\mathrm{x}}\right)$ and $\delta 2.19\left(\mathrm{~s}, 3 \mathrm{H}^{\mathrm{y}}\right)(\mathrm{ESI}$ Fig. S11†). ESI-MS of 3 in water: $m / z$ 131.04, 146.06, and 490.13 (ESI Fig. S12†).

Elemental analysis of complex $4\left(\mathrm{C}_{18} \mathrm{H}_{24} \mathrm{~N}_{6} \mathrm{O}_{6} \mathrm{SPt}\right)$ gave; $\mathrm{C}=$ $33.17 \%$ (33.38); $\mathrm{H}=3.38 \%$ (3.74) and $\mathrm{N}=12.64 \%$ (12.98) where the numbers in parentheses were calculated from the chemical formula. Electronic absorption spectrum of 4 in water, $\lambda_{\max } / \mathrm{nm}$ $\left(\varepsilon / \mathbf{M}^{-1} \mathrm{~cm}^{-1}\right): 273$ (3053). Selected IR frequencies (KBr disk, $\left.\mathrm{cm}^{-1}\right)$ : 3420(br), 3267(br), 3026(br), 2923(w), 1644(s), 1537(s), 1396(s), 1277(m), 1088(s), 748(m), 626(s) and 436(w) (ESI Fig. S13†). ${ }^{1} \mathrm{H}$ NMR (400 MHz, $\delta$ in ppm, $\left.\mathrm{D}_{2} \mathrm{O}\right)$ data: $\delta 7.87(\mathrm{~d}, J=$ $\left.3.6 \mathrm{~Hz}, 1 \mathrm{H}^{\mathrm{k}}\right), \delta 7.69\left(\mathrm{~d}, J=2 \mathrm{~Hz}, 1 \mathrm{H}^{\mathrm{f}}\right), \delta 7.44-7.42\left(\mathrm{~m}, 2 \mathrm{H}^{\mathrm{g}, \mathrm{h}}\right)$, $\delta 6.46\left(\mathrm{~s}, 2 \mathrm{H}^{\mathrm{a}}\right), \delta 4.58\left(\mathrm{~s}, 1 \mathrm{H}^{\mathrm{n}}\right), \delta 4.19\left(\mathrm{~s}, 2 \mathrm{H}^{\mathrm{b}}\right), \delta 3.87\left(\mathrm{~s}, 1 \mathrm{H}^{\mathrm{v}}\right)$, $\delta 3.76\left(\mathrm{t}, J=5.2 \mathrm{~Hz}, 1 \mathrm{H}^{\mathrm{s}}\right), \delta 2.96\left(\mathrm{~m}, 2 \mathrm{H}^{\mathrm{m}}\right), \delta 2.49-2.52\left(\mathrm{~m}, 2 \mathrm{H}^{\mathrm{q}}\right)$ and $\delta 2.12-2.15\left(\mathrm{~m}, 2 \mathrm{H}^{\mathrm{r}}\right)$ (ESI Fig. S14 $\dagger$ ). ESI-MS of 4 in water: $m /$ $z$ 131.04, 146.06, 454.08 and 646.04 (ESI Fig. S15†).

Synthesis safety note: perchlorate salts of metal complex should be handled cautiously as these are hazardous and explosive upon heating. No explosive event was encountered in the present study.

\section{Determination of $\mathrm{p} K_{\mathrm{a}}$ values of complex 2}

The $\mathrm{p} K_{\mathrm{a}}$ values of 2 were determined by potentiometric measurement using standard $0.025 \mathrm{M} \mathrm{KOH}$ solution. Standard buffer solutions prepared according to NBS specifications were used to calibrate the electrode and titro-processor. $\mathrm{p} K_{\mathrm{a}}$ values

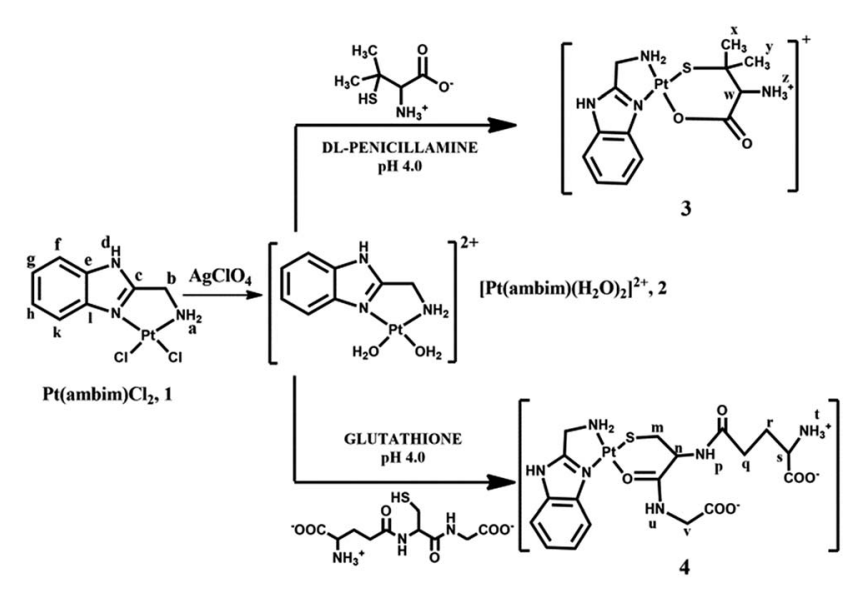

Fig. 1 Structures of complexes and ligands. 
were measured by $\mathrm{pH}$ versus volume titration of $1.50 \times 10^{-4}(\mathrm{M})$ complex 2 and the ionic strength was adjusted to $0.1 \mathrm{M}$ with $\mathrm{NaClO}_{4}$, at $25{ }^{\circ} \mathrm{C}$. The $\mathrm{pH}$ was plotted against volume of base consumed (Fig. 2).

Two equivalent points EP1 and EP2 were observed in the titration curve corresponding to the $\mathrm{p} K_{\mathrm{a}}$ values as HP1 and HP2. The $\mathrm{p} K_{\mathrm{a}_{1}}$ and $\mathrm{p} K_{\mathrm{a}_{2}}$ values of complex 2 were found to be 4.98 and 6.65 respectively, which are comparable with the reported $\mathrm{p} K_{\mathrm{a}}$ values of similar $\left[\mathrm{Pd}(\operatorname{ambim})\left(\mathrm{H}_{2} \mathrm{O}\right)_{2}\right]^{2+}$ system. $^{32}$

\section{Kinetic investigation}

The usual mixing technique was followed and pseudo-firstorder reaction conditions were employed throughout the kinetic runs for the reactions. The progress of the reaction was followed by measuring the increase in absorbance for the ligands with complex 2 at $240 \mathrm{~nm}$ and $245 \mathrm{~nm}$ respectively, where the spectral differences between complex 2 and the product complex $\mathbf{3}$ and $\mathbf{4}$ is at maximum. The $\mathrm{pH}$ and ionic strength were maintained at 4.0 and $0.1 \mathrm{~mol} \mathrm{dm}^{-3}$ (with $\mathrm{NaClO}_{4}$ ) respectively. The method of Weyh and $\mathrm{Hamm}^{33}$ was adopted to calculate the rate constants for both the kinetic studies. The rate data, represented as an average of duplicate runs, were reproducible to within $\pm 4 \%$.

\section{Computational details}

All geometry optimization and energy calculations of complex 1-4 were performed using Density Functional Theory (DFT) at the $\mathrm{B} \mathrm{LYP}^{\mathbf{3 4 , 3 5}}$ level of theory for the complexes 1-4 using Gaussian 09 software. ${ }^{36}$ Global minimum optimized structures were confirmed by frequency analysis at the same level of theory. The relativistic effective core potential (ECP) and associated valence double $\xi$ (zeta) basis set of Hay and $\mathrm{Wadt}^{37,38}$ (LANL2DZ) were employed for Pt atom. The standard split valence basis set $6-31 \mathrm{G}(\mathrm{d})^{39,40}$ was applied for carbon, oxygen, nitrogen, hydrogen and sulfur. Natural bond orbital ${ }^{\mathbf{4 1}}$ (NBO) analysis was performed to get an insight into the electronic structure and bonding of complexes 3 and 4 . To evaluate the nature of the orbitals involved in the transitions related to the experimental observations, Time Dependent-Density Functional Theory (TD-DFT) computational method was applied.

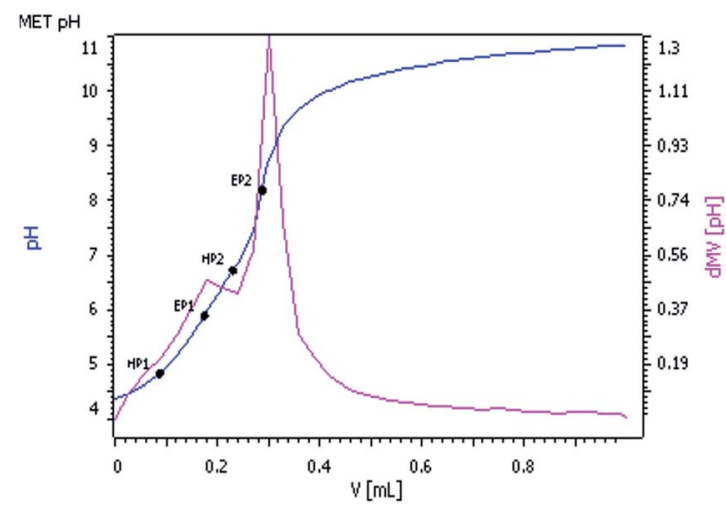

Fig. $2 \mathrm{pH}$ vs. volume $(\mathrm{mL})$ of $0.025 \mathrm{M} \mathrm{KOH}$ solution.
Molecular docking studies were performed using the AutoDock Vina program. ${ }^{42}$ Two structures of B-DNA were selected: a dodecamer d(CGCGATATCGCG) $)_{2}$ (1DNE) for groove binding and an octamer d(GAAGCTTC) $)_{2}$ (1DSC) for intercalation..$^{43}$ Each of the complexes was docked with B-DNA. The water molecules and the ligands were removed from the B-DNA before carrying out docking calculations. The binding site was centred on DNA and a grid box was generated with $40 \times 40 \times 60$ points and a 1.0 Å grid spacing involving almost entire macromolecule. All other parameters were kept at their default values.

\section{DNA binding studies}

All spectroscopic titrations were carried out at room temperature in Tris- $\mathrm{HCl}$ buffer ( $5 \mathrm{mM}$ Tris- $\mathrm{HCl}, 50 \mathrm{mM} \mathrm{NaCl}, \mathrm{pH} 7.4$, Tris $=$ Tris(hydroxymethyl)amino methane).

Interaction of complexes 2-4 with CT-DNA has been studied with UV spectroscopy in order to investigate the probable binding mode. The absorption titration experiments were performed with a constant concentration of the complexes $(20 \mu \mathrm{M})$, while varying [complex]/[CT DNA] mixing ratio in the range 0.1 to 1.0. To obtain the absorption spectra, the required amount of CT-DNA was added to both sample and reference cell to eliminate the absorbance of CT-DNA itself. Complex-DNA solutions were allowed to incubate for 15 minutes before the absorption spectra were recorded. From the absorption titration data, the binding constant $\left(K_{\mathrm{b}}\right)$ was determined using the equation ${ }^{\mathbf{4 4}}$

$$
[\mathrm{DNA}] /\left(\varepsilon_{\mathrm{a}}-\varepsilon_{\mathrm{f}}\right)=[\mathrm{DNA}] /\left(\varepsilon_{\mathrm{b}}-\varepsilon_{\mathrm{f}}\right)+1 /\left\{K_{\mathrm{b}}\left(\varepsilon_{\mathrm{b}}-\varepsilon_{\mathrm{f}}\right)\right\}
$$

where [DNA] is the concentration of CT-DNA in base pairs, $\varepsilon_{\mathrm{a}}, \varepsilon_{\mathrm{f}}$, $\varepsilon_{\mathrm{b}}$ corresponds to the extinction coefficient of observed $\left(A_{\mathrm{obsd}}\right)$ $[\mathrm{M}]$ ), free complex and of the complex when fully bound to CTDNA respectively. The ratio of slope to intercept in the plot of [DNA] $/\left(\varepsilon_{\mathrm{a}}-\varepsilon_{\mathrm{f}}\right)$ versus [DNA] gave the value of $K_{\mathrm{b}}$.

The molecular fluorophore EtBr (3,8-diamino-5-ethyl-6phenylphenanthridinium bromide) emits intense fluorescence in the presence of CT-DNA due to its strong intercalation between the adjacent DNA base pairs. The study involves the addition of the complexes to DNA pretreated with EtBr and the measurement of the intensity of emission. The DNA-EtBr complex was prepared by adding $20 \mu \mathrm{M}$ EtBr and $20 \mu \mathrm{M}$ CT-DNA in buffer. The interaction of complexes 2-4 with the DNA-EtBr complex was studied by adding a certain amount of the complex solution step by step into the solution of DNA-EtBr complex. The effect of the addition was obtained by recording the variation of fluorescence emission spectra with excitation wavelength at $537 \mathrm{~nm}$ and emission wavelength at 550 to $750 \mathrm{~nm}$ after 15 minutes of incubation period in each case. The complexes under study do not show any fluorescence emission band at room temperature in solution or in the presence of CTDNA under the same experimental conditions. Therefore, the observed quenching is characteristic to the displacement of EtBr from its EtBr-DNA complex. To investigate the quenching efficiency, the spectra were analyzed according to the classical Stern-Volmer equation ${ }^{45}$

$$
I_{0} / I=1+K_{\mathrm{SV}}[\mathrm{Q}]
$$


where $I_{0}$ and $I$ are the fluorescence intensities at $580 \mathrm{~nm}$ in the absence and presence of the quencher ' $Q$ ' respectively. $K_{\mathrm{SV}}$ is the linear Stern-Volmer quenching constant which is obtained directly from the slope of $I_{0} / I$ versus [Q] plot where [Q] is the concentration of the quencher. The apparent binding constant $\left(K_{\text {app }}\right)$ is determined from the equation ${ }^{46}$

$$
K_{\mathrm{EtBr}}[\mathrm{EtBr}]=K_{\mathrm{app}}[\mathrm{Q}]
$$

in which [Q] is the concentration of the quencher causing a 50\% reduction in the fluorescence intensity of EtBr-bound DNA, $K_{\mathrm{EB}}$ $=1.0 \times 10^{7} \mathrm{M}^{-1}$ and $[\mathrm{EtBr}]=20 \mu \mathrm{M}$. In fluorimetric titration studies, the binding constant $K_{\mathrm{F}}$ is determined from the Scatchard equation. ${ }^{47}$

$$
\log \left(F_{0}-F\right) / F=\log K_{\mathrm{F}}+n \log [\mathrm{Q}]
$$

The plot of $\log \left(F_{0}-F\right) / F$ versus $\log [\mathrm{Q}]$ is drawn and fitted linearly, and then the $n$ value, the number of binding sites per nucleotide, can be obtained from the slope.

\section{Bioactivity studies}

Cell lines, culture conditions and cytotoxicity assay. Human cervical cancer (HeLa), non-small cell lung carcinoma (A549) and hepatocellular liver carcinoma (HepG2) cell lines were used for investigation of cytotoxicity of the complexes. The cells were cultured in DMEM containing 10\% FBS and 1\% of penicillin/ streptomycin (50 IU mL $\mathrm{mL}^{-1}$ and $500 \mathrm{mg} \mathrm{L}^{-1}$ ). The cultures were grown in $25 \mathrm{~cm}^{2}$ flasks in an incubator at $37{ }^{\circ} \mathrm{C}$ with a humidified atmosphere composed of $5 \% \mathrm{CO}_{2}$.

Normal healthy Swiss albino mice were anesthetised and then liver and lungs tissues were removed after perfusion with sterile PBS. These tissues were minced and digested in PBS containing $0.5 \%$ trypsin for 45 minutes at $37{ }^{\circ} \mathrm{C}$. Cells were separated after tissue digestion by filtration through nylon mesh followed by several wash with PBS. These cells were then kept in DMEM containing 2\% FBS and antibiotics, and finally resuspended in the medium and plated in a six well plate, incubated in a humidified $95 \% \mathrm{O}_{2} / 5 \% \mathrm{CO}_{2}$ atmosphere at $37{ }^{\circ} \mathrm{C}$.

The colorimetric MTT (3-(4,5-dimethylthiazol-2-yl)-2,5diphenyl tetrazolium bromide) assay $^{\mathbf{4 8 , 4 9}}$ was employed to determine the cytotoxicity of the compounds under study. Approximately 10 000-12 000 cells were added to each well of a 96-well plate in DMEM medium. Different doses of ambim, complex 2-4 and cisplatin ranging from 5.0 to $50.0 \mu \mathrm{M}$ concentrations were applied in triplicates for $48 \mathrm{~h}$. Untreated cells and cells treated with cisplatin were used as negative and positive control ${ }^{50}$ respectively. $20 \mu \mathrm{L} \mathrm{MTT} \mathrm{(5} \mathrm{mg} \mathrm{mL}^{-1}$ in PBS) solution was added to each well and incubated for another $3 \mathrm{~h}$. $150 \mu \mathrm{L}$ of DMSO was added to each well to dissolve the blue formazan product. The absorbance of this product was measured at $540 \mathrm{~nm}$, using ELISA plate reader. ${ }^{51}$ The $\mathrm{IC}_{50}$ (the concentration of tested agent that caused $50 \%$ inhibition of cell growth) values were obtained from the results of triplicate determinations of at least three independent experiments.
Similar procedure was followed for the evaluation of viability of mice liver and lung cells.

ROS assay. Around 1000 cells were taken in $200 \mu \mathrm{L}$ media in each well of a 96-well plate and then incubated with $50 \mu \mathrm{M}$ of the complexes 2-4 for $4 \mathrm{~h}$. Untreated cells and cells treated with $50 \mu \mathrm{M}$ of cisplatin were used as negative and positive control respectively. The media was removed and the cells were washed twice with PBS. $25 \mu \mathrm{L}$ of NBT solution $\left(1 \mathrm{mg} \mathrm{mL}^{-1}\right.$ in water) was added to each well and incubated for another $3 \mathrm{~h}$. The cells were again washed with PBS twice and $150 \mu \mathrm{L}$ DMSO was added for solubilization of formazan crystals. After complete solubilization, $20 \mu \mathrm{L}$ of $2 \mathrm{mM}$ potassium hydroxide was added and OD was measured at $620 \mathrm{~nm}$ in a Beckman DU 730 spectrophotometer. All animal experiments were performed in compliance with the relevant laws and institutional guidelines of Institutional Animal Ethics Committee (IAEC), Visva-Bharati University (Registration No. 1819/GO/Ere/S/15/(CPCSEA) and these experiments were approved by IAEC, Visva-Bharati University.

Microscopic observation of cells. HeLa, A549 and HepG2 cells were allowed to grow in $100 \mathrm{~mm}$ culture plates containing DMEM with 10\% FBS and appropriate amount of penicillin/ streptomycin. To acquire around $70 \%$ confluence, they were incubated at $37{ }^{\circ} \mathrm{C}$ in $5 \% \mathrm{CO}_{2}$. These cells were treated with 10 $\mu \mathrm{M}$ concentrations of ambim, complexes 2-4 and cisplatin followed by the incubation for $24 \mathrm{~h}$. Negative control plate was also maintained, where the cells remain untreated. These plates were washed with $1 \times$ PBS and used to capture images by inverted microscope with $100 \times$ magnification.

Gel electrophoresis. Agarose gel electrophoresis experiment was performed ${ }^{52,53}$ to explore the interaction and the effect of the complexes on plasmid DNA (pcDNA3) as the target. Aliquots of $150 \mathrm{ng}$ of plasmid DNA treated with complexes 2-4 in a final volume of $20 \mu \mathrm{L}$, were incubated for 30 minutes at $37^{\circ} \mathrm{C} .5 \mu \mathrm{L}$ of loading buffer (consisting of $0.25 \%$ bromophenol blue, $0.25 \%$ xylene cyanol $\mathrm{FF}$ and $30 \%$ glycerol in water) was added in the wells of $1 \%$ agarose gel. The electrophoresis was run for $2 \mathrm{~h}$ at 60 volt using $0.5 \times$ TBE buffer $(\mathrm{pH} 8.0)$. Lane 1 is untreated DNA, lane 2 is DNA treated with $50 \mu \mathrm{M}$ of cisplatin and lanes 3-7 are DNA treated with $50 \mu \mathrm{M}$ and $100 \mu \mathrm{M}$ of complexes 2-4 respectively.

\section{Results and discussion}

\section{Spectroscopic analyses}

Electronic spectra and TD-DFT. The UV-vis spectrum of the complex 1 (Fig. 3) shows that there are two absorption bands at 273 and $280 \mathrm{~nm}$, which are due to metal perturbed intra-ligand transitions. The band in the simulated spectrum appears at 283 $\mathrm{nm}$ which is in good agreement to the experimentally obtained spectrum. The peak at $273 \mathrm{~nm}$ arises from HOMO-1 to LUMO+1 transition but does not feature in the simulated spectrum due to its low oscillatory strength. The experimental and theoretical $\lambda_{\max }$ values corresponding to bands observed for the electronic transitions are given in Table 1 . The major contribution of molecular orbitals involved in the electronic transitions is shown in ESI Fig. S16. $\dagger$ 


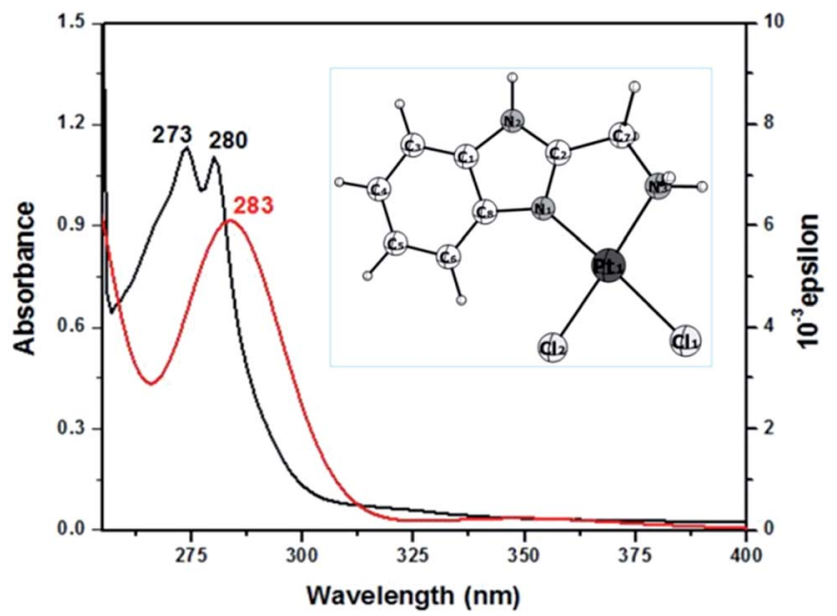

Fig. 3 UV-vis (in black) and simulated TD-DFT (in red) spectrum of complex 1 in DMSO. Inset: optimised structure of complex 1.

Table 1 TD-DFT and experimental band position of $\left[\mathrm{Pt}(\mathrm{ambim}) \mathrm{Cl}_{2}\right]$ in DMSO

\begin{tabular}{lll}
\hline $\begin{array}{l}\text { Experimental band } \\
\left(\varepsilon \mathrm{dm}^{3} \mathrm{~mol}^{-1} \mathrm{~cm}^{-1}\right)\end{array}$ & $\begin{array}{l}\text { TD-DFT peaks } \\
\text { (oscillator strength) }\end{array}$ & Major contribution \\
\hline 280 & $283(0.0715)$ & HOMO $\rightarrow$ L+1 $(95 \%)$ \\
273 & $274(0.0038)$ & H-1 $\rightarrow$ L $+1(91 \%)$
\end{tabular}

Electronic spectra of the substituted products $\mathbf{3}$ and $\mathbf{4}$ display different $\lambda_{\max }$ values in aqueous medium with hypsochromic $(\sim 6 \mathrm{~nm})$ and bathochromic $(\sim 2 \mathrm{~nm})$ shift with respect to complex 2 . The spectral changes of the products are due to $n \rightarrow$ $\pi^{*}$ and $\pi \rightarrow \pi^{*}$ transitions of the coordinated ligands in complex 3 and $\mathbf{4}$, which indicate the formation of new products.

Infrared spectra. The most important bands in the spectrum of free DL-pen are assigned to $\nu_{\mathrm{st}}\left(\mathrm{NH}_{3}^{+}\right)$at $3174-2967 \mathrm{~cm}^{-1}$ and $\nu_{\text {as }}\left(\mathrm{COO}^{-}\right)$at $1595 \mathrm{~cm}^{-1}$ corresponding to its zwitterionic form. ${ }^{54}$ No shift in the $\nu_{\text {as }}\left(\mathrm{NH}_{3}{ }^{+}\right)$band is observed which confirms non-involvement of $-\mathrm{NH}_{2}$ group in coordination. The absorption bands of $\nu_{\text {as }}\left(\mathrm{COO}^{-}\right)$in complex 3 shifted to higher frequency $\left(1640 \mathrm{~cm}^{-1}\right)$, whereas the $\nu_{\mathrm{s}}\left(\mathrm{COO}^{-}\right)$shifted to lower frequency $\left(1345 \mathrm{~cm}^{-1}\right)$ indicating terminal coordination mode of the carboxylate group to the metal ion. ${ }^{55}$ The $\nu(\mathrm{S}-\mathrm{H})$ band at $2600-2400 \mathrm{~cm}^{-1}$ in the free ligand is found to be missing in the spectrum of complex 3 suggesting coordination through $-\mathrm{SH}$ group. In this spectrum, $\nu(\mathrm{Pt}-\mathrm{S})$ also appears at $436 \mathrm{~cm}^{-1}$.

The peak appearing at $3026 \mathrm{~cm}^{-1}$ for the zwitterionic form of $\mathrm{GSH}^{56}$ due to $\mathrm{N}-\mathrm{H}$ stretching in a $\mathrm{H}$-bonded $\mathrm{NH}_{3}{ }^{+}$, shows no considerable shift in the spectrum of complex 4 . The strong band at $2525 \mathrm{~cm}^{-1}$ due to $\nu(\mathrm{S}-\mathrm{H})$ is also absent indicating coordination by thiol group and a band at $436 \mathrm{~cm}^{-1}$ can be assigned to $\nu(\mathrm{Pt}-\mathrm{S})$. The bands at 1537 and $1396 \mathrm{~cm}^{-1}$ in GSH are assigned to $\nu_{\mathrm{as}}\left(\mathrm{COO}^{-}\right)$and $\nu_{\mathrm{s}}\left(\mathrm{COO}^{-}\right)^{57}$ which show no considerable shift in the spectrum of 4 suggesting nonparticipation of the carboxylate group in complex formation. Moreover, the band at $1713 \mathrm{~cm}^{-1}$ is due to the $-\mathrm{C}=\mathrm{O}$ stretching vibration of the carboxylate group of glycine residue of GSH, which confirms its non-involvement in coordination to $\mathrm{Pt}(\mathrm{II}){ }^{56}$ The band at $1665 \mathrm{~cm}^{-1}$ in free GSH assigned to $>\mathrm{C}=\mathrm{O}$ stretching of peptide bond, has shifted to lower frequency (1644 $\mathrm{cm}^{-1}$ ) indicating coordination of carbonyl group of the cysteine residue to $\mathrm{Pt}(\mathrm{III})^{58}$ resulting in a preferred six-membered chelate.

A decrease in $\mathrm{pH}$ on mixing complex 2 with DL-pen (from 4.0 to 2.71) and GSH (from 4.0 to 2.96) corroborates with sulphur coordination. The high affinity of $\mathrm{Pt}$ (II) for sulphur provides the driving force for deprotonation of the thiol groups in the first step of complex formation. These findings are consistent with bidentate coordination through $\mathrm{S}$ and $\mathrm{O}$ atoms shown by DL-pen and GSH in complexes 3 and 4.

${ }^{1} \mathbf{H}$ NMR spectra. The $-\mathrm{SH}$ resonance signal of free DL-pen (1.0-2.0 ppm) is missing in the spectrum of 3 (in DMSO-d6), accompanied by a shift in the signals of the adjacent methyl groups which is consistent with its coordination to $\mathrm{Pt}(\mathrm{II})$. The signal for the amino group remains unchanged at $6.10 \mathrm{ppm}$ (ref. 59) indicating non-involvement in coordination. The carboxylate group must thus chelate to the metal centre, which is supported by a shift in the signal of the proton attached to the chiral carbon in DL-pen moiety.

The resonance signals of the $\alpha$ and $\beta$ protons of cysteine residue in the GSH moiety appear at slightly downfield positions in the spectrum of $\mathbf{4}$, which corroborates the coordination of $\mathrm{Pt}$ (II) by thiol and peptide carbonyl. The acidic protons are missing in the spectrum due to exchange with the solvent $\mathrm{D}_{2} \mathrm{O}$. The protons in the aromatic region appear at 8.51-8.27 ppm and 7.87-7.44 ppm in complexes 3 and 4 respectively (as compared to 8.03-7.38 ppm in complex 2), confirming the presence of ambim moiety in the complexes.

\section{ESI mass}

The formation of metal complexes and various ionic forms in aqueous solution were studied with ESI-MS. The peak at $m / z 490$ in the spectrum of 3 indicates the formation of the product $\left[\mathrm{Pt}(\mathrm{II})+\text { ambim }+ \text { DL-pen- } \mathrm{H}^{+}\right]^{+}$. Similarly for complex 4, molecular ion peak corresponding to $\left[\mathrm{Pt}(\mathrm{II})+\operatorname{ambim}+\mathrm{GSH}-2 \mathrm{H}^{+}\right]$is found at $m / z$ 646. The molecular ion peaks of 3 and 4 were accompanied by isotope peaks with expected relative abundance. Base peak obtained at $m / z 131$ for both the complexes can be tentatively assigned to a methylium cation generated by the loss of $-\mathrm{NH}_{2}$ unit from ambim. A prominent peak at $m / z 146$ observed in the spectra of $\mathbf{3}$ and $\mathbf{4}$ can be attributed to just the ambim moiety after removal of platinum metal and the ligand. The expulsion of ambim and $-\mathrm{CO}_{2}$ from the GSH moiety, probably gives rise to the peak at $m / z 454$ in the spectrum of 4 .

\section{Kinetic study}

The acid dissociation constants of DL-pen and GSH at $25^{\circ} \mathrm{C}$ are $1.81(-\mathrm{COOH}) \quad 7.96\left(\mathrm{NH}_{3}^{+}\right), \quad 10.72(\mathrm{SH})$ and $2.12(\mathrm{COOH})$, 3.59(COOH), 8.75( $\left.\mathrm{NH}_{3}{ }^{+}\right), 9.65(\mathrm{~S}-\mathrm{H})$ respectively. ${ }^{60,61}$ Thus, both DL-pen and GSH exist in their zwitterionic forms at $\mathrm{pH}$ 4.0. The $\mathrm{p} K_{\mathrm{a}_{1}}$ and $\mathrm{p} K_{\mathrm{a}_{2}}$ values of the complex 2 were found to be 4.98 and 6.65 respectively. We can thus assume that at $\mathrm{pH} 4.0$ the reactant complex 2 exists as diaqua species. At a particular 


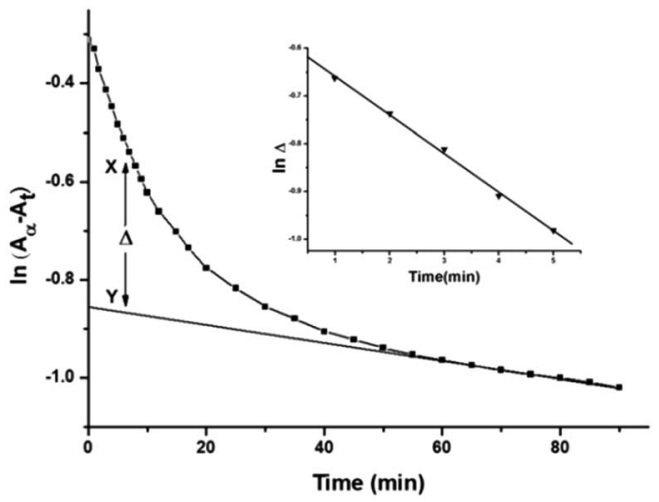

Fig. 4 A typical plot of $\ln \left(A_{\alpha}-A_{t}\right)$ vs. time: [complex 2] $=1.50 \times 10^{-4}$ $\mathrm{M} ;$ [DL-pen] $=1.50 \times 10^{-3} \mathrm{M} ; 25^{\circ} \mathrm{C}$. Inset: typical plot of $\ln \Delta$ vs. time (min).

temperature, $\mathrm{pH} 4.0$ and fixed concentration of complex 2, the plots of $\ln \left(A_{\alpha}-A_{t}\right)$ versus time (where, $A_{\alpha}$ and $A_{t}$ are the absorbances at infinite time i.e. after the completion of the reaction and at time $t$ ) for various ligand concentrations were curved at the initial stage and subsequently of constant slope (Fig. 4 for DL-pen and ESI Fig. S17† for GSH). This indicates that the reaction proceeds through a two-step consecutive process and we propose that in the first step one aqua ligand is replaced from 2 by the sulphur atom of the ligands. The second step is slower, where the other aqua molecule is substituted and ring closure takes place.

The rate constants for such a two step process can be evaluated by assuming the following scheme (Scheme 1):

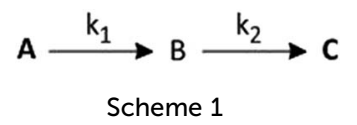

Where, A is the diaqua complex 2, B is the sulfur bonded (one aqua ligand substituted intermediate, and $\mathrm{C}$ is the final product, 3 and $\mathbf{4}$. Formation of $\mathrm{C}$ from $\mathrm{B}$ is predominant after some time has elapsed.

\section{Evaluation of $\boldsymbol{k}_{\mathbf{1}}$ for $\mathrm{A} \rightarrow$ B step}

At each temperature, the rate constant $k_{1(\mathrm{obs})}$ values were evaluated by the method of Weyh and $\mathrm{Hamm}^{33}$ from the plots of $\ln \Delta$ (the variation of $\Delta$ is shown in Fig. 4, inset) versus time (where $t$ is small) and are collected in ESI Table S1.† Using the usual consecutive rate law:

$$
\left(A_{\alpha}-A_{t}\right)=a_{1} \exp \left(-k_{1(\mathrm{obs})} t\right)+a_{2} \exp \left(-k_{2(\mathrm{obs})} t\right)
$$

where, $a_{1}$ and $a_{2}$ are constants that depend on the rate constant and extinction coefficient. The values of $\left[\left(A_{\alpha}-A_{t}\right)-a_{2^{-}}\right.$ $\left.\exp \left(-k_{2(\mathrm{obs})} t\right)\right]$ were obtained from the parameter $X-Y$ at different times.

$$
\ln \Delta=\text { constant }-k_{1(\mathrm{obs})} t
$$

where, $\Delta$ is the difference between the observed and extrapolated part of the linear portion of $\left(A_{\alpha}-A_{t}\right)$ versus time (when $t$ is small). Hence, $k_{1(\mathrm{obs})}$ is derived from the slope of the plot of $\ln \Delta$ versus $t$.

The same procedure was followed in the range of ligand concentration from $1.50 \times 10^{-3} \mathrm{~mol} \mathrm{dm}^{-3}$ to $4.50 \times 10^{-3} \mathrm{~mol}$ $\mathrm{dm}^{-3}$, at constant complex 2 concentration $\left(1.50 \times 10^{-4} \mathrm{~mol}\right.$ $\left.\mathrm{dm}^{-3}\right)$ and at different temperatures $\left(25,30,35,40\right.$ and $\left.45^{\circ} \mathrm{C}\right)$. The reaction rate increases with increasing ligand concentration up to a limiting value (ESI Fig. S18 $\dagger$ for DL-pen and S19 for $\mathrm{GSH})$. The dependency of the $k_{1 \text { (obs) }}$ values on ligand concentration can be explained in terms of rapid formation of an outer sphere association complex between the reactant complex 2 and ligand in the step $\mathrm{A} \rightarrow \mathrm{B}$. Since the metal ion reacts with its immediate surroundings, further change in ligand concentration beyond the saturation point will not affect the reaction rate and a gradual approach towards limiting rate is observed. This is followed by inner sphere association through sulfur coordination via displacement of one water molecule resulting in the intermediate B (Scheme 2). The following scheme can be proposed for the reaction:

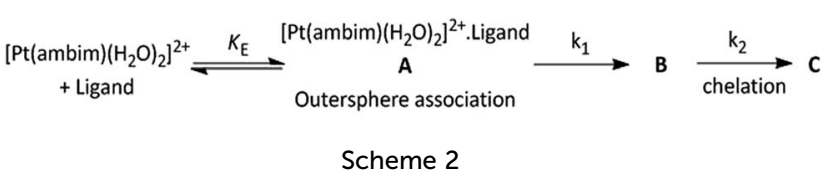

Based on the above equations, a rate expression (6) can be derived for the $\mathrm{A} \rightarrow$ B step:

$$
\begin{gathered}
\mathrm{d}[\mathrm{B}] / \mathrm{d} t=k_{1} K_{\mathrm{E}}[2][\text { ligand }] /\left(1+K_{\mathrm{E}}[\text { ligand }]\right) \\
\mathrm{d}[\mathrm{B}] / \mathrm{d} t=k_{1(\text { obs })}[2]_{T}
\end{gathered}
$$

where subscript $T$ stands for total concentration of complex (2), thus

$$
1 / k_{1(\mathrm{obs})}=1 / k_{1}+1 / k_{1} K_{\mathrm{E}}[\text { ligand }]
$$

where, $k_{1}$ is the rate constant for the formation of (B) and $K_{\mathrm{E}}$ is the outer sphere association equilibrium constant. A plot of $1 /$ $k_{1 \text { (obs) }}$ versus $1 /$ [ligand] (Fig. 5 for DL-pen and ESI Fig. S20 $\dagger$ for $\mathrm{GSH}$ ) was found to be linear with an intercept of $1 / k_{1}$ and a slope of $1 / k_{1} K_{\mathrm{E}}$. This equation is applicable to all the temperatures under the kinetic study. The first step rate constant $k_{1}$ and $K_{\mathrm{E}}$ values (Table 2) were obtained from the intercept $\left(1 / k_{1}\right)$ and from the slope-to-intercept ratios $\left(1 / k_{1} K_{\mathrm{E}}\right)$.

\section{Evaluation of $\boldsymbol{k}_{2}$ for $\mathrm{B} \rightarrow \mathrm{C}$ step}

The second step involves displacement of another water molecule accompanied by ring closure through the second donor site of the ligands. Due to steric hindrance, this chelation step is slower and independent of ligand concentration. At each temperature, the $k_{2 \text { (obs) }}$ values were calculated from the limiting linear portion (when $t$ is large) of the plot of $\ln \left(A_{\alpha}-A_{t}\right)$ versus $t$ (Fig. 4) and the values are collected in ESI Table S2.† Unlike $k_{1}$, 


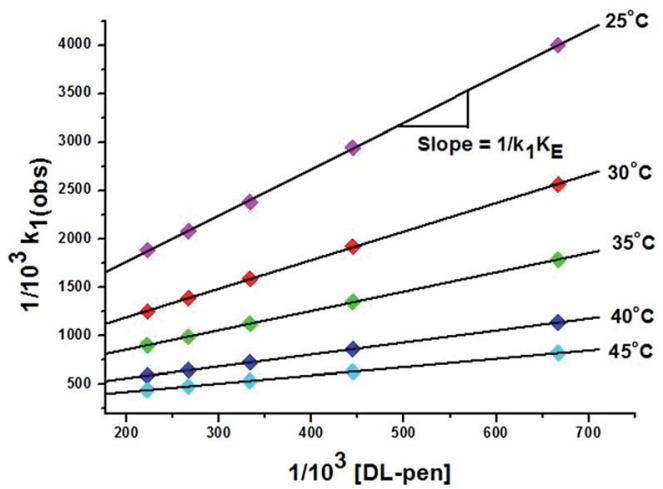

Fig. 5 Plot of $1 / 10^{3} \times k_{1 \text { (obs) }}$ versus $1 / 10^{3}$ [DL-pen] at different temperatures.

$k_{2}$ values (listed in Table 2 ) were found to be independent of ligand concentration at all temperatures studied.

The derived rate equation of the reactions based on kinetic observations is as follows,

$$
\text { Rate }=\frac{k_{1} K_{\mathrm{E}}[\text { ligand }]}{1+K_{\mathrm{E}}[\text { ligand }]}[\text { complex } 2]+k_{2}[\text { complex } 2]
$$

where, $K_{\mathrm{E}}=$ outer sphere association equilibrium constant.

\section{Effect of temperature and $\mathbf{p H}$}

The reactions were studied at five different temperatures at different ligand concentrations and the substitution rate constants for both the steps $\left(k_{1}\right.$ and $\left.k_{2}\right)$ are given in Table 2. The activation parameters calculated from Eyring plots (ESI Fig. S21 and S22 † for DL-pen and S23, S24 for GSH) are given in Table 3 and compared with those for substitution reactions on analogous square planar Pt(II) systems (ESI Table $\mathrm{S} 3 \dagger$ ).

The reactions were studied at six different $\mathrm{pH}$ values. At a fixed [complex 2], [ligand] and $0.1 \mathrm{M}$ ionic strength, $k_{(\mathrm{obs})}$ values for both the steps increases initially from $\mathrm{pH} 3.0$ to 4.0 and decreases from 5.0 to 7.4. For formation of complex $3,10^{3}$ $\times k_{1 \text { (obs) }}$ values at $25{ }^{\circ} \mathrm{C}$ were $0.19,0.25,0.17,0.12,0.09$ and $0.05 \mathrm{~s}^{-1}$ and $10^{5} \times k_{2(\mathrm{obs})}$ values were $0.94,1.03,0.86,0.74,0.52$ and $0.41 \mathrm{~s}^{-1}$ at $\mathrm{pH} 3.0,4.0,5.0,6.0,6.8$ and 7.4 respectively. Similar trend is observed in case of complex 4 . The increase in rate may be explained on the basis of acid dissociation equilibria of the ligands and complex 2 . In the studied $\mathrm{pH}$ range, 2 exists as diaqua species till its first $\mathrm{p} K_{\mathrm{a}_{1}}$ value (4.98). After that the diaqua species is transformed to a bridging dimer, ${ }^{62,63}$ which reacts with the ligands at a comparatively slower rate. The rate enhancement up to $\mathrm{pH} 4.0$ might be explained by the deprotonation and increased donor ability of the ligands. At higher $\mathrm{pH}$, the percentage of bridged dimer is maximum, consequently the rate decreases. Hence, the substitution reactions were followed at a constant $\mathrm{pH}$ of 4.0 to avoid complication from an additional parameter of $\left[\mathrm{H}^{+}\right]$in the rate equation.

\section{Mechanism}

Based on the result of Job's method of continuous variation and the spectroscopic data, bidentate ligation by DL-pen and GSH has been suggested. Being a soft base, the sulphur donor centres of the ligands attack the soft Pt(II) centre first. From the low values of enthalpy of activation $\left(\Delta H_{1}^{*}\right.$ and $\left.\Delta H_{2}^{\ddagger}\right)$ and high negative values of entropy of activation $\left(\Delta S_{1}^{\ddagger}\right.$ and $\left.\Delta S_{2}^{\ddagger}\right)$, an associative mechanism is proposed (Scheme 3) for both the ligand substitution reactions. Furthermore, $\Delta S_{2}^{\star}$ is found to be more negative than $\Delta S_{1}^{\dagger}$, which suggests that compactness has already been achieved in $\mathrm{B}$ and the transformation of $\mathrm{B}$ to $\mathrm{C}$ is by displacement of another aqua ligand through chelation. Thus, complex formation occurs via a rapid outer sphere association, followed by two consecutive steps: the first being dependent of [ligand] and the second being a slower ring closure step which is independent of [ligand]. The plausible mechanism for the interaction of complex 2 with DL-pen and GSH is shown as follows:

Table 2 Rate constants for the $\left[\mathrm{Pt}(\operatorname{ambim})\left(\mathrm{H}_{2} \mathrm{O}\right)_{2}\right]^{2+}$ with DL-pen and $\mathrm{GSH}$ at pH 4.0 and $0.1 \mathrm{M} \mathrm{NaClO}_{4}$

\begin{tabular}{|c|c|c|c|c|c|c|}
\hline Temp. $\left({ }^{\circ} \mathrm{C}\right)$ & \multicolumn{3}{|l|}{ DL-pen } & \multicolumn{3}{|l|}{ GSH } \\
\hline 30 & $1.65 \pm 0.15$ & $206.65 \pm 0.16$ & $1.46 \pm 0.04$ & $4.20 \pm 0.12$ & $372.91 \pm 0.17$ & $4.00 \pm 0.03$ \\
\hline 35 & $2.18 \pm 0.09$ & $229.16 \pm 0.19$ & $1.98 \pm 0.03$ & $5.29 \pm 0.10$ & $406.39 \pm 0.22$ & $4.82 \pm 0.04$ \\
\hline 40 & $3.16 \pm 0.11$ & $258.32 \pm 0.24$ & $2.61 \pm 0.05$ & $6.40 \pm 0.09$ & $448.82 \pm 0.18$ & $5.76 \pm 0.02$ \\
\hline
\end{tabular}

Table 3 Activation parameters

\begin{tabular}{|c|c|c|c|c|}
\hline Systems & $\Delta H_{1}^{*}\left(\mathrm{~kJ} \mathrm{~mol}^{-1}\right)$ & $\Delta S_{1}^{\ddagger}\left(\mathrm{J} \mathrm{K} \mathrm{mol}{ }^{-1}\right)$ & $\Delta H_{2}^{\star}\left(\mathrm{kJ} \mathrm{mol}^{-1}\right)$ & $\Delta S_{2}^{*}\left(\mathrm{~J} \mathrm{~K} \mathrm{~mol}^{-1}\right)$ \\
\hline$\left[\mathrm{Pt}(\text { ambim })\left(\mathrm{H}_{2} \mathrm{O}\right)_{2}\right]^{2+} /$ DL-pen & $43.79 \pm 1.31$ & $-149.00 \pm 1.20$ & $38.7 \pm 1.16$ & $-205.12 \pm 1.78$ \\
\hline$\left[\mathrm{Pt}(\operatorname{ambim})\left(\mathrm{H}_{2} \mathrm{O}\right)_{2}\right]^{2+} / \mathrm{GSH}$ & $31.04 \pm 1.44$ & $-184.65 \pm 1.17$ & $26.46 \pm 1.19$ & $-239.16 \pm 1.61$ \\
\hline
\end{tabular}



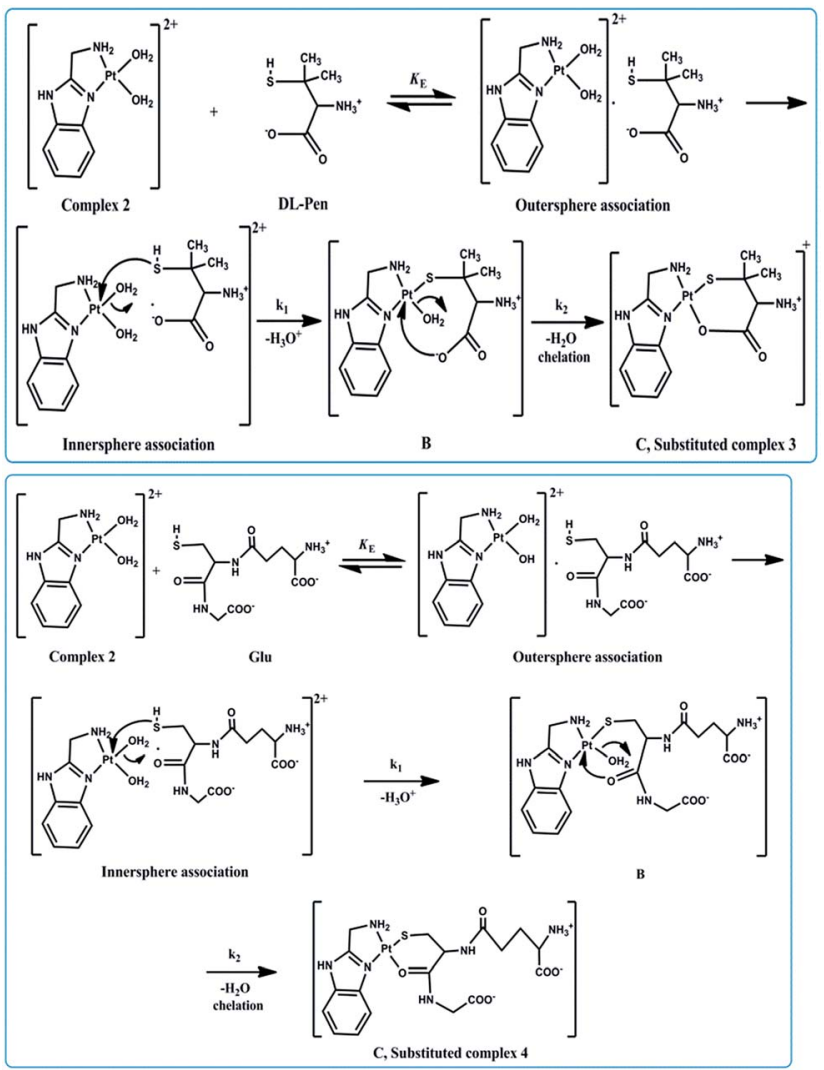

Scheme 3 Plausible mechanism of the reactions between complex 2 with DL-pen and GSH.

\section{Computational study}

A list of bond distances [̊] and angles [deg] obtained from optimized geometry (ESI Fig. S25†) for complexes 2-4 (comparable with reported data for closely related structures $\left.{ }^{\mathbf{6 4 , 6 5}}\right)$ is presented in Table 4 .

The surface plots of HOMO and LUMO for complexes 2-4 and their energies are shown in Fig. 6. Positive and negative regions are shown in red and green colours respectively. HOMO and LUMO calculation of complex 2 reveals that electron

Table 4 Selected bond distances $(\AA)$ and bond angles $\left({ }^{\circ}\right)$ of complexes 2-4 calculated from optimized structures

$$
2
$$$$
3
$$$$
4
$$

References $^{64,65}$

\begin{tabular}{lllll}
\hline \multicolumn{2}{l}{ Bond distance $(\stackrel{\AA}{\mathbf{A}})$} & & & \\
Pt-N1 & 1.988 & 2.043 & 2.048 & 2.030 \\
Pt-N3 & 2.068 & 2.179 & 2.196 & 2.039 \\
Pt-S1 & N.A. & 2.327 & 2.326 & 2.356 \\
Pt-O2 & N.A. & 2.040 & 2.037 & 2.055
\end{tabular}

Bond angle $\left({ }^{\circ}\right)$

$\mathrm{N} 1-\mathrm{Pt}-\mathrm{N} 3$

$\mathrm{N} 3-\mathrm{Pt}-\mathrm{O} 2$

80.30

$\mathrm{N} 1-\mathrm{Pt}-\mathrm{O} 1$

100.40

79.27

$\mathrm{N} 3-\mathrm{Pt}-\mathrm{O} 2$

95.94

N.A.

$\mathrm{O} 2-\mathrm{Pt}-\mathrm{S} 1$
N.A.

N.A.

87.88

95.56
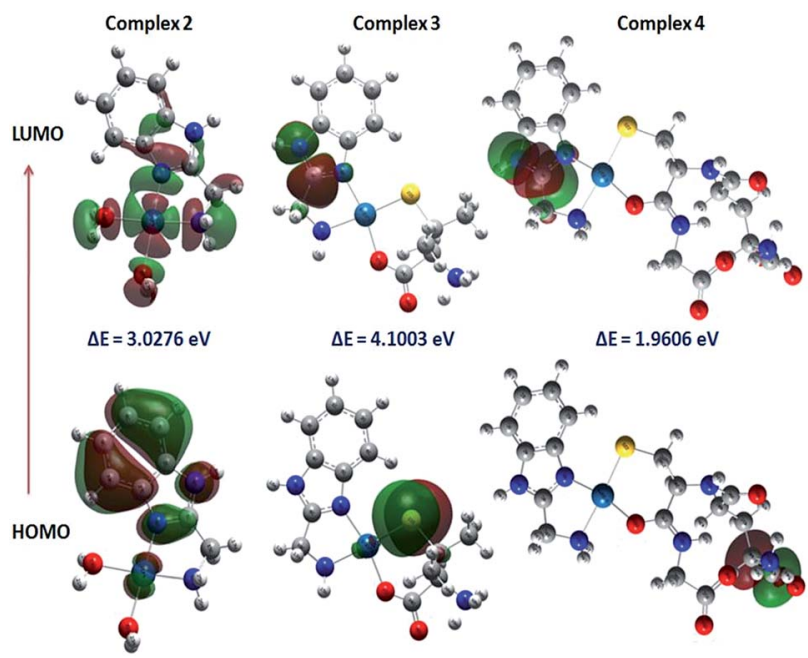

Fig. 6 Counter plots of HOMO and LUMO of complexes 2-4.

density of HOMO is localized mostly on benzimidazole ring of carrier ligand ambim and minimum on the metal ion without significant contributions. But the charge density of HOMO for 3 and 4 is localised on DL-pen and glutathione part of the complex respectively, whereas LUMO is localised on ambim.

\section{NBO calculation}

NBO analysis provides detailed insight into the nature of electronic structure and bonding in the product complexes $\mathbf{3}$ and $\mathbf{4}$ by considering chelation through $(\mathrm{S}, \mathrm{O})$ and $(\mathrm{S}, \mathrm{N})$ in the substitution reaction. Calculated atomic charges and electronic configurations for complex $3(\mathrm{~S}, \mathrm{O})$ and $4(\mathrm{~S}, \mathrm{O})$ and the probable complexes $\mathbf{3}^{\prime}(\mathrm{S}, \mathrm{N})$ and $\mathbf{4}^{\prime}(\mathrm{S}, \mathrm{N})$ (ESI Fig. S26 ${ }^{\dagger}$ ) are listed in ESI Tables S4 and S5. $\dagger$ By comparing the zero-point corrected energies, it can be concluded that $(\mathrm{S}, \mathrm{O})$ coordination is preferred over $(\mathrm{S}, \mathrm{N})$, which corroborates the spectroscopic results.

Table 5 lists the calculated occupancies (electron densities) on NBO orbitals, hybrids on atoms and polarities of bonds between atoms. According to these results, the platinum atom in $\mathbf{3}$ and $\mathbf{4}$ forms sigma bond with S1 atoms of the thiol groups of DL-pen and GSH respectively. The coordination bonds between Pt and the imidazole N1, amino N2 and oxygen O2 (of carboxylate and amidic carbonyl oxygen) can be described as a donation of electron density from donor orbitals to Pt acceptor orbitals.

\section{Interaction with CT-DNA}

Electronic absorption titration. The changes observed in the UV spectra upon titration may give evidence of the existing interaction mode, since a hypochromism due to $\pi \rightarrow \pi^{*}$ stacking interactions may appear in the case of the intercalative binding mode, while a red-shift (bathochromism) may be observed when the DNA duplex is stabilized. ${ }^{66,67}$ Again, hyperchromism is indicative of partial or non-intercalative binding 
Table 5 Occupancy (e) and polarity (\%) of natural bond orbitals (NBOs) and hybrids calculated for 3 and $4^{a}$

\begin{tabular}{|c|c|c|c|c|c|}
\hline Complex & NBO orbital ${ }^{b}$ & Occupancy (e) & Polarity $^{c}(\%)$ & NBO hybrid & $\mathrm{AO}^{d}(\%)$ \\
\hline \multirow[t]{4}{*}{3} & $\sigma(\mathrm{Pt}-\mathrm{S} 1)$ & 1.9797 & $38.05(\mathrm{Pt})$ & $\mathrm{sd}^{3.03}$ & $\mathrm{~s}(23.13 \%) \mathrm{p}(6.86 \%) \mathrm{d}(70.01 \%)$ \\
\hline & & & 61.95(S1) & $\mathrm{sp}^{6.26}$ & $\mathrm{~s}(13.74 \%) \mathrm{p}(86.03 \%) \mathrm{d}(0.23 \%)$ \\
\hline & LP(N1) & 1.6191 & - & $\mathrm{sp}^{2.79}$ & $\mathrm{~s}(26.38 \%) \mathrm{p}(73.61 \%) \mathrm{d}(0.00 \%)$ \\
\hline & $\mathrm{LP}(\mathrm{N} 3)$ & 1.7256 & - & $\mathrm{sp}^{4.92}$ & $\mathrm{~s}(16.90 \%) \mathrm{p}(83.10 \%) \mathrm{d}(0.00 \%)$ \\
\hline \multirow[t]{3}{*}{4} & $\sigma(\mathrm{Pt}-\mathrm{S} 1)$ & 1.9823 & $39.73(\mathrm{Pt})$ & $\mathrm{sd}^{3.10}$ & $\mathrm{~s}(22.84 \%) \mathrm{p}(6.38 \%) \mathrm{d}(70.78 \%)$ \\
\hline & LP(N1) & 1.6359 & - & $\mathrm{sp}^{2.21}$ & $\mathrm{~s}(31.13 \%) \mathrm{p}(68.87 \%) \mathrm{d}(0.01 \%)$ \\
\hline & LP(N3) & 1.7106 & - & $\mathrm{sp}^{5.15}$ & $\mathrm{~s}(16.26 \%) \mathrm{p}(83.74 \%) \mathrm{d}(0.00 \%)$ \\
\hline
\end{tabular}

${ }^{a}$ Calculations performed at the B3LYP/6-31G(D)/LANL2DZ of theory. ${ }^{b} \mathrm{LP}(\mathrm{N} / \mathrm{O})$ is a valence lone pair orbital on nitrogen/oxygen atom. ${ }^{c}$ Values for the A-B sigma molecular orbital. ${ }^{d}$ Percentage contribution of atomic orbitals in NBO hybrid.

modes, such as dative bonds, electrostatic forces, hydrogen bonds, van der Waals forces and hydrophobic interactions. ${ }^{68}$

The absorption spectra of 2-4 in the absence and presence of CT-DNA (at a constant concentration of complexes) are given in Fig. 7, ESI Fig. S27 and S28. $\dagger$ As seen in the figures, the complexes exhibit intense absorption bands at 260-275 nm assigned to intraligand transitions of the aromatic chromophore. Addition of increasing amounts of CT-DNA results in hypochromism accompanied by a bathochromic shift of about 8 and 7-8 $\mathrm{nm}$ for 2 and 3, while hyperchromism is observed for 4 with no shift in the absorption maxima.

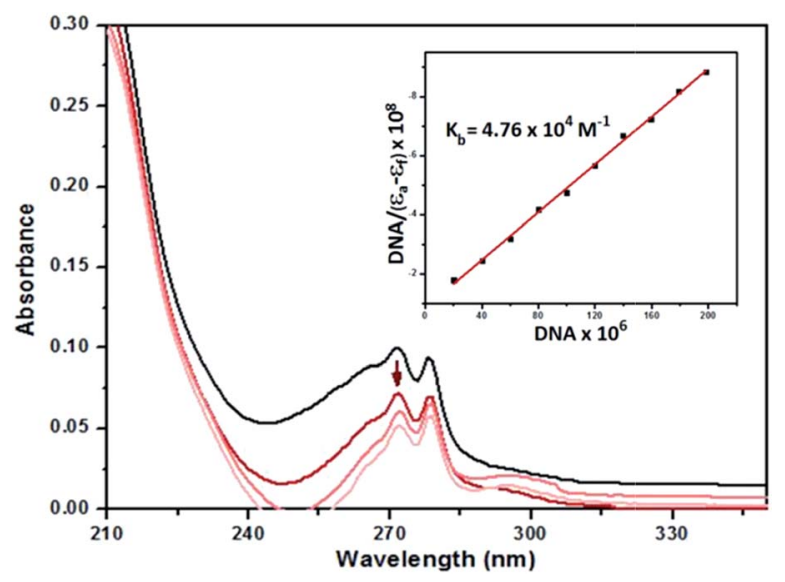

Fig. 7 UV spectra of $2(20 \mu M)$ in Tris- $\mathrm{HCl}$ buffer in the presence of increasing amounts of CT-DNA $(0-200 \mu \mathrm{M})$. The arrow indicates decrease in the absorbance on additions of DNA. Inset: linear fit of $[D N A] /\left(\varepsilon_{a}-\varepsilon_{f}\right) v s$. [DNA].
The outcome of the UV titration experiments suggest that all the complexes bind to CT-DNA. The existence of hypochromism for complexes $\mathbf{2}$ and $\mathbf{3}$ may be considered as evidence that the complexes bind to DNA via intercalation ${ }^{67}$ while the opposite effect for 4 suggests surface binding. The magnitude of the binding strength of the complexes with CT-DNA can be estimated through the binding constant. The $K_{\mathrm{b}}$ values (Table 6) suggest a moderate to strong binding of the complexes to CTDNA with complex 2 exhibiting the highest $K_{\mathrm{b}}$. The $K_{\mathrm{b}}$ values of the complexes (Table 6) are lower than the classical intercalator EtBr binding affinity for CT-DNA, $\left(K_{\mathrm{b}}=1.23( \pm 0.07) \times\right.$ $\left.10^{5} \mathrm{M}^{-1}\right) .^{69}$

\section{Competitive studies with ethidium bromide}

The complexes show no fluorescence at room temperature in solution or in the presence of CT-DNA, and their binding to DNA cannot be directly predicted through the emission spectra. On the other hand, free EtBr does not exhibit significant emission in buffer solution due to fluorescence quenching by the solvent molecules, while its fluorescence intensity is highly enhanced upon addition of CT-DNA, due to its strong intercalation with DNA base pairs. Thus, competitive EtBr binding studies were carried out so as to investigate the binding of each complex with DNA.

The addition of 2-4 to the solutions of CT-DNA pretreated with EtBr caused obvious reduction in emission intensity, indicating that the complexes compete with $\mathrm{EtBr}$ in binding to CT-DNA (Fig. 8 and ESI Fig. S29 and S30†). The binding constants $\left(K_{\mathrm{app}}, K_{\mathrm{F}}\right)$, quenching constants $\left(K_{\mathrm{SV}}\right)$, number of binding sites $(n)$ are listed in Table 6 . The $K_{\mathrm{SV}}$ values for the

Table 6 The binding constants $\left(K_{\mathrm{b}}, K_{\mathrm{app}}, K_{\mathrm{F}}\right)$, quenching constants $\left(K_{\mathrm{Sv}}\right)$, number of binding sites $(n)$ for the interaction of $2-4$ with CT-DNA

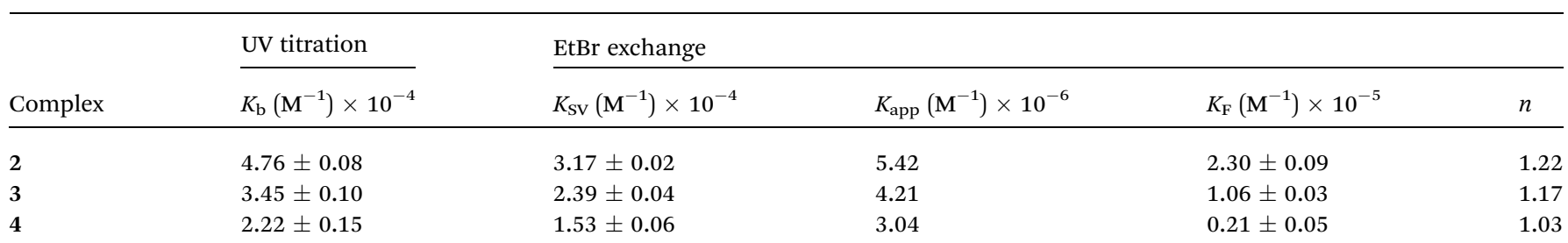




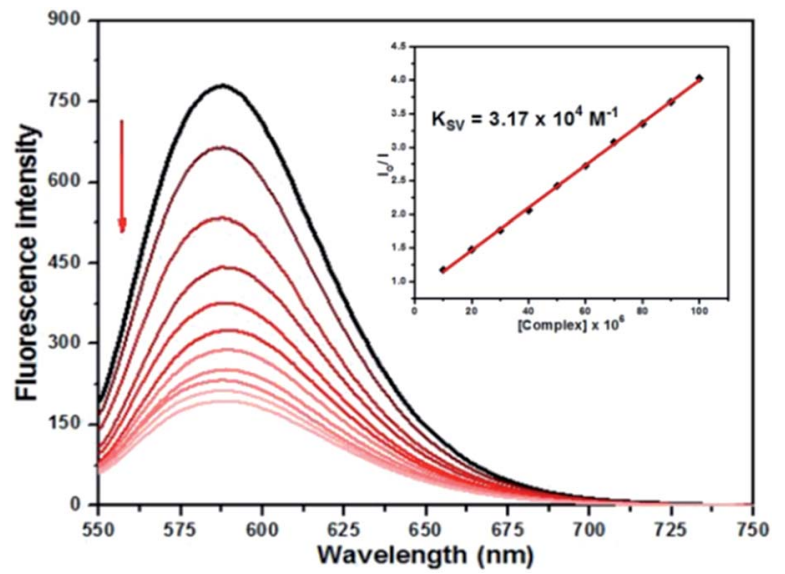

Fig. 8 Emission spectra of EtBr-bound DNA solutions in the absence and presence of increasing concentrations of $2(10-100 \mu \mathrm{M})$ in Tris$\mathrm{HCl}$. [EtBr] $=20.0 \mu \mathrm{M}$, [DNA] $=20.0 \mu \mathrm{M}$. The arrow shows the change in intensity upon increasing amounts of the complex. Inset: SternVolmer plot of the fluorescence data.

complexes are in the range of $1.53 \times 10^{4}$ to $3.17 \times 10^{4} \mathrm{M}^{-1}$, respectively, suggesting that EtBr molecules are effectively displaced from the DNA binding sites. The $K_{\mathrm{F}}$ values calculated from Scatchard plots (ESI Fig. S31 $\dagger$ ) are found to be $5.42 \times 10^{5}$, $4.21 \times 10^{5}$, and $3.04 \times 10^{5}$ for $2-4$, respectively, indicating that 2 presents the highest binding propensity and the order of binding strength of the complexes to CT-DNA is $2>3>4$, being the same as observed in the UV titration studies. The $n$ values around 1.0 well correspond to a $1: 1$ molar ratio between the complexes and CT-DNA.

\section{Molecular docking}

AutoDock has been used for rigid molecular docking studies with DNA duplex of sequence d(CGCGAATTCGCG) $)_{2}$ (1DNE) dodecamer and an octamer d(GAAGCTTC) $)_{2}$ (1DSC). Complexes 2-4 were successively docked into DNA to predict the
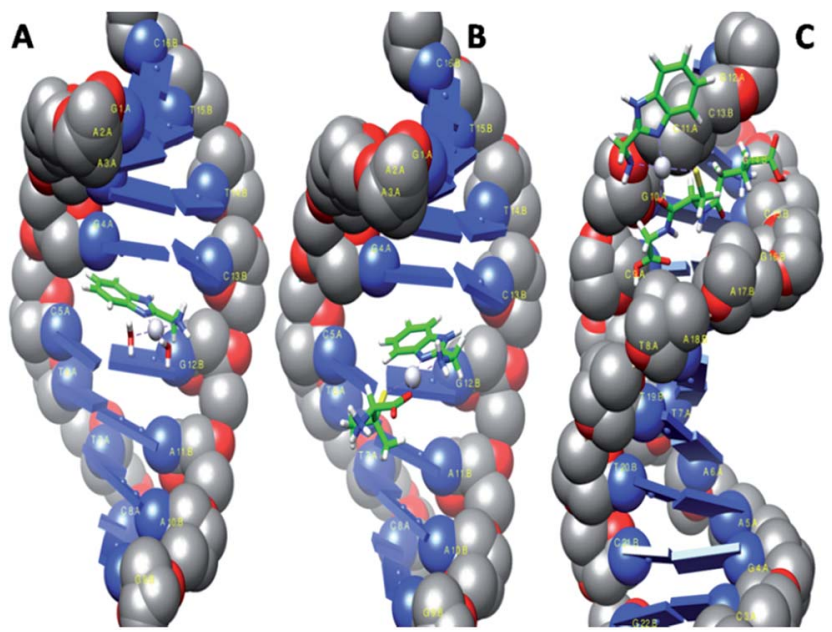

Fig. 9 Computational docking models illustrating the interactions of 2 (A) and 3 (B) with 1DNE and of 4 (C) with 1DSC. appropriate binding site and preferred orientation inside the DNA duplex. The lowest-energy conformations of the docked structures of 2-4 are illustrated in Fig. 9 and the magnified views in ESI Fig. S32. $\dagger$ The planarity of the ambim moiety is compatible for $\pi-\pi$ stacking interactions with the DNA base pairs and indeed, it is seen that complexes 2 and 3 intercalates in the G-C rich region of the DNA structure. On the other hand, the minimum energy docked pose of 4 reveals that it fits into the curved contour of the targeted DNA in the minor groove. The large GSH moiety in 4 increases its steric bulk, possibly preventing any intercalative interaction. Complex $\mathbf{4}$ is mainly stabilized by hydrogen bonding through the $\mathrm{NH}$ groups of the GSH moiety while the interaction of 2 and 3 with DNA is dominated by $\pi-\pi$ interactions with the benzimidazole ring of ambim ligand. On the whole, these interactions (ESI Table S6†) contribute significantly to the stabilization of each complex within the DNA duplex. The binding free energies of the docked structures were computed to be $-30.25,-30.12$ and $-28.45 \mathrm{~kJ}$ $\mathrm{mol}^{-1}$ for 2, 3 and 4 respectively. The calculated values are consistent with the trend obtained from the absorption titration and fluorescence quenching studies of CT-DNA (Table 6) and indicate greater binding affinity of 2 relative to the other complexes.

\section{DNA cleavage study}

The chemical nuclease activity of 2-4 was studied using pCDNA3 plasmid DNA by agarose gel electrophoresis in the absence of any external effect such as UV light, reducing and oxidizing agents. The efficiency of the complexes was assessed by their ability to convert the closed circular supercoiled form of the DNA (form I) to the open circular relaxed or nicked form (form II) or the linear form (form III). The complexes were found to promote the cleavage of the plasmid DNA from supercoiled form to nicked form (lanes 2, 4 and 6, ESI Fig S33†). The mobility of the bands decreases with increasing concentration of the complexes. Moreover, bands for both form I and II are depleted and appear more faint at higher concentration (100 $\mu \mathrm{M}$ ) of the complexes (lanes 3, 5 and 7) indicating degradation of plasmid DNA into undetectable single-stranded fragments. The smear that appears in the lanes 2-7 may result from the displacement of EtBr used to stain DNA in the gel by the complexes due to strong interaction. From the gel picture, it can be concluded that complex 2 shows considerably higher DNA cleavage activity than $\mathbf{3}$ and $\mathbf{4}$.

\section{Cytotoxicity of complexes 2-4 and $\mathrm{IC}_{50}$ values}

The encouraging results obtained from the DNA binding studies have directed us to investigate the cell growth inhibition of the synthesised complexes. In vitro cytotoxicity tests were performed using the MTT assay, following exposure of three tumor cell lines: human cervical cancer (HeLa), non-small cell lung carcinoma (A549) and hepatocellular liver carcinoma (HepG2) to the synthesized complexes at increasing concentrations for $48 \mathrm{~h}$. Data for cisplatin and the spectator ligand, ambim, under the same conditions have been also reported for comparison. These complexes exhibit dose-dependent growth 

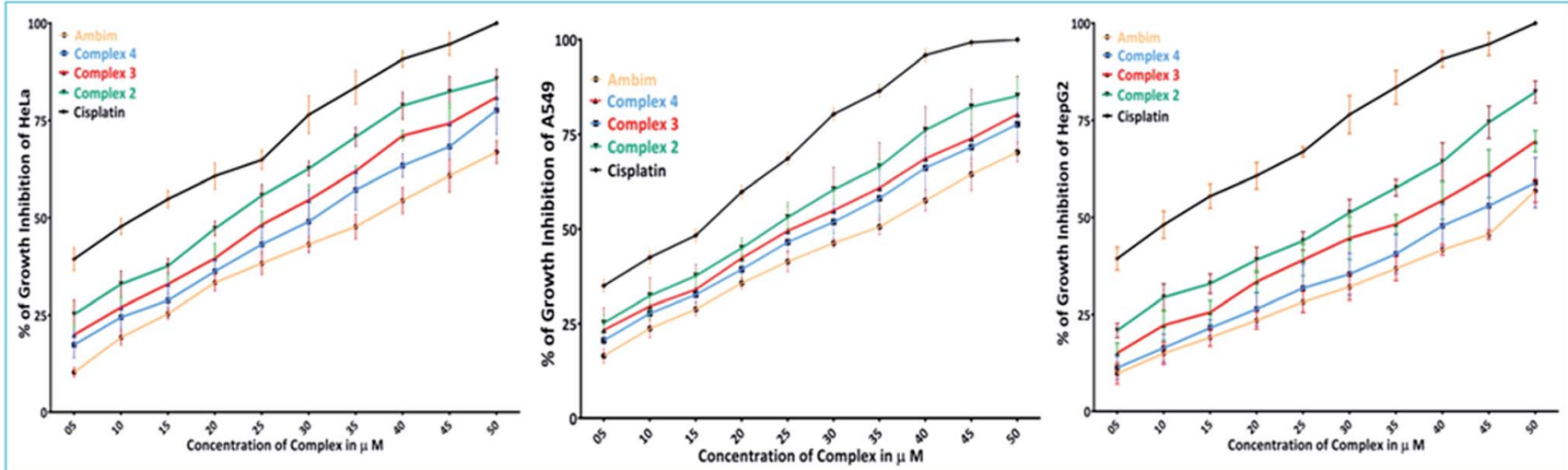

Fig. 10 Percentage of growth inhibition of HeLa, A549 and HepG2 cells in presence of ambim, complex 2-4 and cisplatin at concentrations from $5.0 \mu \mathrm{M}$ to $50.0 \mu \mathrm{M}$. All determinations are expressed as percentage of the control (untreated cells).

inhibitory effect against the tested cell lines and the concentration-response curves are shown in Fig. 10.

The $\mathrm{IC}_{50}$ values derived from dose-response curves are summarised in Table 7 and they are comparable to those of cisplatin. Among the compounds studied here, complex 2 is the most cytotoxic in all the three cell lines tested while $\mathbf{4}$ is the least.

The complexes were more effective in arresting the growth of HeLa and A549 than HepG2. It is noteworthy that metal-free ambim was significantly active against all the cell lines at the $48 \mathrm{~h}$ time point.

\section{Cell morphology observation}

Fig. 11 shows the morphological changes of untreated and treated HepG2 cells observed under a light inverted microscope. The control cells were irregular confluent aggregates with rounded and polygonal cells. The cells treated with complexes 2-4 (B-D), ambim (E) and cisplatin (F) appeared to shrink, became spherical in shape and the cell spreading patterns were restricted (Fig. 11BF). There is a notable reduction in cell number brought about by the complexes, though the effect is more pronounced for cisplatin. Similar observations were made for HeLa (ESI Fig. S34 $\dagger$ ) and A549 (ESI Fig. S35†) cells after being treated with the complexes.

\section{Assessment of viability and ROS levels in mice liver and lung cells}

It is now well-known that cisplatin exposure results in oxidative stress in normal cells which leads to its non-specific toxicity. ${ }^{7}$

Table 7 Cytotoxicities of ambim, 2-4 and cisplatin in HeLa, A549 ad HepG2 cells

\begin{tabular}{llll}
\hline & \multicolumn{2}{l}{$\mathrm{IC}_{50} \pm \mathrm{SD}, \mu \mathrm{M}$} & \\
\cline { 2 - 4 } Compounds & HeLa & A549 & HepG2 \\
\hline Ambim & $37 \pm 0.9$ & $36 \pm 0.8$ & $46 \pm 1.0$ \\
$\mathbf{2}$ & $22 \pm 0.6$ & $24 \pm 0.7$ & $29 \pm 0.4$ \\
$\mathbf{3}$ & $26 \pm 0.5$ & $26 \pm 1.1$ & $37 \pm 0.6$ \\
$\mathbf{4}$ & $31 \pm 1.0$ & $29 \pm 0.4$ & $43 \pm 0.8$ \\
Cisplatin & $12 \pm 0.9$ & $16 \pm 0.6$ & $13 \pm 1.2$
\end{tabular}

Excessive reactive oxygen species (ROS) are generated which damage cellular proteins, lipids and DNA, ensuing cell death or apoptosis. Hence, though complexes 2-4 demonstrate marked anti-cancer activity, an obvious question that could be raised is whether they are toxic to normal cells. To have an answer to this, we tested their cytotoxic effect on normal mice liver and lung cells. It is interesting to note that the complexes did not show any adverse effect on normal cells as evidenced from the MTT assay (Fig. 12 and ESI Fig. S36†).

Besides evaluating cell viability, we also checked the level of superoxides or ROS generated in the afore-mentioned cells, which is an important parameter to determine cellular stress.

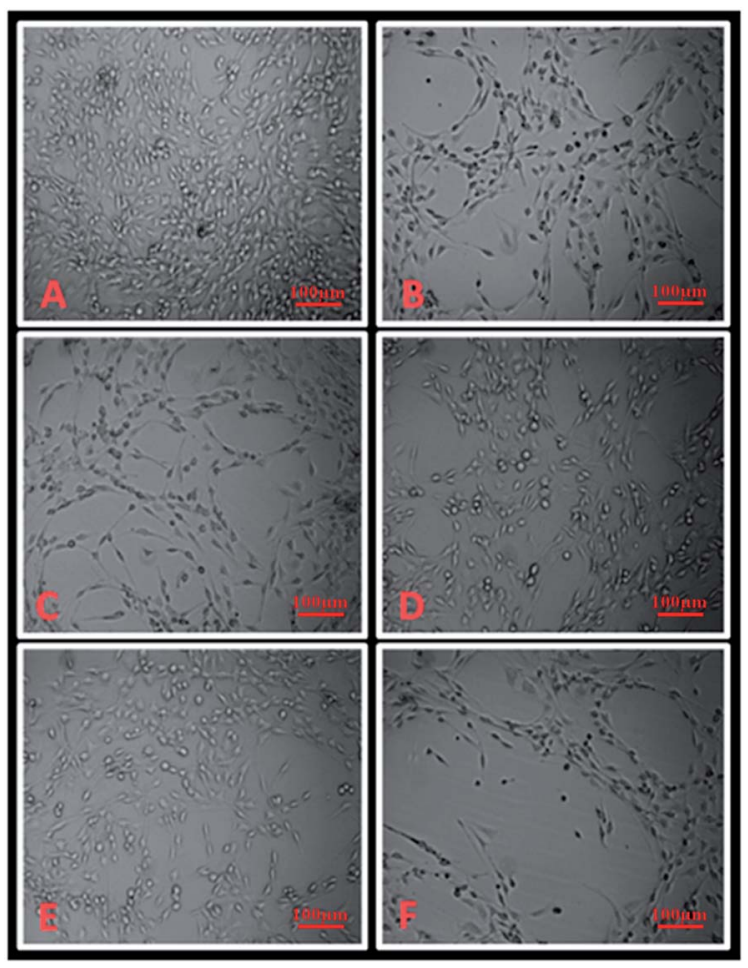

Fig. 11 Microscopic images (A) untreated HepG2 cells, (B) treated with $10 \mu \mathrm{M}$ of complex 2, (C) complex 3, (D) complex 4, (E) ambim and (F) cisplatin. 


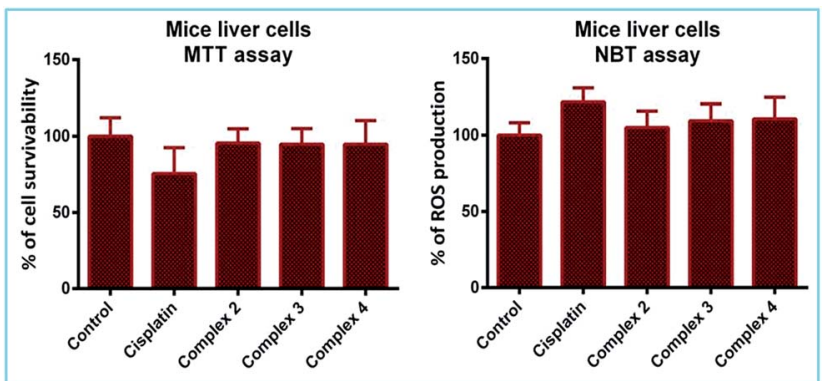

Fig. 12 Percentage of cell survivability and ROS production in mice liver cells after $4 \mathrm{~h}$ incubation with $50 \mu \mathrm{M}$ of cisplatin and complexes $2-4$.

The results from the NBT assay indicate that ROS production in the cells treated with complexes 2-4 remains almost the same as compared to the control and also lower than those treated with cisplatin (Fig. 12 and ESI Fig. S36†). This suggests that the complexes are not toxic to normal cells, which is a crucial criterion for a practical anti-cancer agent.

\section{Conclusions}

The dichloro Pt(II) complex 1, bearing the main ligand, 2-aminomethylbenzimidazole, its diaqua analogue, 2 and the thiolsubstituted complexes $\mathbf{3}$ and $\mathbf{4}$ have been synthesised and characterized in detail by elemental analysis, NMR, IR and ESIMS. DL-Penicillamine and glutathione coordinates to $\mathrm{Pt}(\mathrm{II})$ centre in complex 2 through $\mathrm{S}$ and $\mathrm{O}$ donors to form six membered complexes $\mathbf{3}$ and $\mathbf{4}$ via two consecutive steps. The low values of the enthalpies of activation $\left(\Delta H_{1}^{*}\right.$ and $\left.\Delta H_{2}^{*}\right)$ and large negative values of entropies of activation $\left(\Delta S_{1}^{\ddagger} \& \Delta S_{2}^{\ddagger}\right)$ for both reactions imply a good degree of ligand participation in associative path of the T.S. The trend in the reactivity of the ligands is also reflected in the activation enthalpies of the reactions. The higher nucleophilicity of GSH leads to greater stabilization of the T.S. and hence requires a smaller activation enthalpy as compared to DL-pen. DFT calculations determine the global minimum optimized structures of complexes 2-4, which reveals few important bond distances $(\AA)$ and bond angles $\left({ }^{\circ}\right)$ close to reported values. Electronic spectra calculated by TD-DFT is in good agreement with the observed UV-vis spectra.

Based on the data from absorption and fluorimetric competitive titrations, it can be concluded that the complexes bind strongly to CT-DNA with different binding affinities. The calculated binding constants of the complexes with DNA showed that 2 has the highest binding affinity to DNA. Intercalative binding for complexes $\mathbf{2}$ and $\mathbf{3}$, and minor groove binding for $\mathbf{4}$ was further validated by molecular docking studies. These water soluble complexes are also efficient DNA cleavers and exhibit considerable cytotoxicity on HeLa, A549 and HepG2 cell lines. Based on the $\mathrm{IC}_{50}$ values, the potency of the complexes can be ordered as $\mathbf{2}>\mathbf{3}>\mathbf{4}$. On all the three cell lines, complex 2 shows $82-85 \%$ growth inhibition at higher concentration $(50 \mu \mathrm{M})$ as compared to cisplatin. Most importantly, the complexes were found to generate lower levels of ROS and better viability for normal cells than cisplatin.
Further studies can be undertaken to assess their pharmacological properties in vivo and elucidate the definite mechanism of their bioactivity. The results presented here may be beneficial in understanding the interactions of $\mathrm{Pt}(\mathrm{II})$ complexes with intracellular thiols and DNA and thereby useful in the development of superior anticancer agents.

\section{Acknowledgements}

The authors are thankful to National Institute of Technology Durgapur, W.B. 713209, India and DST, Govt. of India (Project no. SB/EMEQ-028/2013) for providing the necessary assistance and financial support to carry out this work. Ishani Mitra and Subhajit Mukherjee are also thankful to DST Inspire, Govt. of India for research fellowship. Sandip Mukherjee is thankful to DST, SERB N-PDF for research fellowship. We are grateful to the reviewers for their valuable suggestions.

\section{References}

1 B. Rosenberg, in Cisplatin: Chemistry and Biochemistry of a Leading Anticancer Drug, Verlag Helv. Chim. Acta, ed. B. Lippert, Wiley-VCH. Zurich, Weinheim, Germany, 1999, p. 3.

2 M. J. Hannon, Pure Appl. Chem., 2007, 79(12), 2243.

3 S. Dasari and P. Bernard Tchounwou, Eur. J. Pharmacol., 2014, 740, 364.

4 L. Kelland, Nat. Rev. Cancer, 2007, 7, 573.

5 Z. H. Siddik, Oncogene, 2003, 22, 7265.

6 C. A. Rabik and M. E. Dolan, Cancer Treat. Rev., 2007, 33, 9.

7 R. Marullo, E. Werner, N. Degtyareva, B. Moore, G. Altavilla, S. S. Ramalingam and P. W. Doetsch, PLoS One, 2013, 8(11), 81162.

8 Q. Yang, H. Xiao, J. Cai, Z. Xie, Z. Wang and X. Jing, RSC Adv., $2014,4,61124$.

9 Q. Yang, R. Qi, J. Cai, X. Kang, S. Sun, H. Xiao, X. Jing, W. Li and Z. Wang, RSC Adv., 2015, 5, 83343.

10 H. Xiao, L. Yan, Y. Zhang, R. Qi, W. Li, R. Wang, S. Liu, Y. Huang, Y. Li and X. Jing, Chem. Commun., 2012, 48, 10730.

11 H. Xiao, J. F. Stefanick, X. Jia, X. Jing, T. Kiziltepe, Y. Zhang and B. Bilgicer, Chem. Commun., 2013, 49, 4809.

12 R. Qi, H. Xiao, S. Wu, Y. Li, Y. Zhang and X. Jing, J. Mater. Chem. B, 2015, 3, 176.

13 H. Song, W. Li, R. Qi, L. Yan, X. Jing, M. Zheng and H. Xiao, Chem. Commun., 2015, 51, 11493.

14 R. Wang, H. Xiao, H. Song, Y. Zhang, X. Hu, Z. Xie, Y. Huang, X. Jing and Y. Li, J. Mater. Chem., 2012, 22, 25453.

15 R. Wang, X. Hu, H. Xiao, Z. Xie, Y. Huang and X. Jing, J. Mater. Chem. B, 2013, 1, 744.

16 J. K. Barton and S. J. Lippard, Biochemistry, 1979, 18, 2661.

17 B. M. Zeglis, V. C. Pierre and J. K. Barton, Chem. Commun., 2007, 4565.

18 D. M. Fisher, R. R. Fenton and J. R. Aldrich-Wright, Chem. Commun., 2008, 5613.

19 A. C. G. Hotze, E. P. L. van der Geer, H. Kooijman, A. L. Spek, J. G. Haasnoot and J. Reedijk, Eur. J. Inorg. Chem., 2005, 2648. 20 S. Komeda, T. Moulaei, K. K. Woods, M. Chikuma, N. P. Farrell and L. D. Williams, J. Am. Chem. Soc., 2006, 128, 16092. 
21 D. L. Ma, T. Y. T. Shum, F. Zhang, C. M. Che and M. Yang, Chem. Commun., 2005, 4675.

22 A. A. Spasov, I. N. Yozhitsa, L. I. Bugaeva and V. A. Anisimova, Pharm. Chem. J., 1999, 33, 232.

23 G. L. Gravatt, B. C. Baguley, W. R. Wilson and W. A. Denny, J. Med. Chem., 1994, 37, 4338.

24 J. P. Lalezari, J. A. Aberg, L. H. Wang, M. B. Wire, R. Miner, W. Snowden, C. L. Talarico, S. Shaw, M. A. Jacobson and W. L. Drew, Antimicrob. Agents Chemother., 2002, 46, 2969.

25 D. Labrecke, S. Lamothe, M. Courchesne, L. Chan, G. Attardo and K. Meerovitch, Preparation of thiophene-2,5dicarboxamides and furan-2,5-dicarboxamides useful in the treatment of cancer, US Pat., 91063, 1998.

26 W. H. Miller, W. E. Bondinell, T. W. Ku, R. M. Keenan, J. M. Samanen, C. Kwon, F. E. Ali and M. A. Lago, Benzimidazole derivatives and analogs as vitronectin receptor antagonists, US Pat., 9366, 1995.

27 M. A. Jakupec, M. Galanski and B. K. Keppler, Rev. Physiol., Biochem. Pharmacol., 2003, 146, 1.

28 J. Reedijk, Chem. Rev., 1999, 99, 2499.

29 K. S. Lovejoy and S. J. Lippard, Dalton Trans., 2009, 48, 1065. 30 S. H. van Rijt and P. J. Sadler, Drug Discovery Today, 2009, 14, 1089.

31 R. W. Hay and A. K. Basak, J. Chem. Soc., Dalton Trans002E, 1982, 1819.

32 A. A. El-Sherif, in Coordination Chemistry of Palladium(II) Ternary Complexes with Relevant Biomolecules, Stoichiometry and Research - The Importance of Quantity in Biomedicine, ed. A. Innocenti, InTech, 2012, ch. 4, pp. 79-120.

33 J. A. Weyh and R. E. Hamm, Inorg. Chem., 1969, 8, 2298.

34 A. D. Becke, J. Chem. Phys., 1993, 98, 5648.

35 C. Lee, W. Yang and R. G. Parr, Phys. Rev. B: Condens. Matter Mater. Phys., 1988, 37, 785.

36 M. J. Frisch, G. W. Trucks, H. B. Schlegel, G. E. Scuseria, M. A. Robb, J. R. Cheeseman, G. Scalmani, V. Barone, B. Mennucci, G. A. Petersson, H. Nakatsuji, M. Caricato, X. Li, H. P. Hratchian, A. F. Izmaylov, J. Bloino, G. Zheng, J. L. Sonnenberg, M. Hada, M. Ehara, K. Toyota, R. Fukuda, J. Hasegawa, M. Ishida, T. Nakajima, Y. Honda, O. Kitao, H. Nakai, T. Vreven, J. A. Montgomery Jr, J. E. Peralta, F. Ogliaro, M. Bearpark, J. J. Heyd, E. Brothers, K. N. Kudin, V. N. Staroverov, R. Kobayashi, J. Normand, K. Raghavachari, A. Rendell, J. C. Burant, S. S. Iyengar, J. Tomasi, M. Cossi, N. Rega, J. M. Millam, M. Klene, J. E. Knox, J. B. Cross, V. Bakken, C. Adamo, J. Jaramillo, R. Gomperts, R. E. Stratmann, O. Yazyev, A. J. Austin, R. Cammi, C. Pomelli, J. W. Ochterski, R. L. Martin, K. Morokuma, V. G. Zakrzewski, G. A. Voth, P. Salvador, J. J. Dannenberg, S. Dapprich, A. D. Daniels, Ö. Farkas, J. B. Foresman, J. V. Ortiz, J. Cioslowski and D. J. Fox, Gaussian 09, Revision D.01, Gaussian, Inc., Wallingford CT, 2009.

37 P. J. Hay and W. R. Wadt, J. Chem. Phys., 1985, 82, 299.

38 P. J. Hay and W. R. Wadt, J. Chem. Phys., 1985, 82, 284.

39 R. Ditchfield, W. J. Hehre and J. A. Pople, J. Chem. Phys., 1971, 54, 724.

40 W. Hehre, J. R. Ditchfield and J. A. Pople, J. Chem. Phys., 1972, 56, 2257.
41 D. E. Glendening, A. E. Reed, J. E. Carpenter and F. Weinhold, NBO, Version 3.1.

42 O. Trott and A. J. Olson, J. Comput. Chem., 2010, 3, 455.

43 C. G. Ricci and P. A. Netz, J. Chem. Inf. Model., 2009, 49, 1925.

44 A. M. Pyle, J. P. Rehmann, R. Meshoyrer, C. V. Kumar,

N. J. Turro and J. K. Barton, J. Am. Chem. Soc., 1989, 111, 3051.

45 O. Stern and M. Volmer, Phys. Z., 1919, 20, 183.

46 M. Lee, A. L. Rhodes, M. D. Wyatt, S. Forrow and J. A. Hartley, Biochemistry, 1993, 32, 4237.

47 J. Min, X. M. Meng-Xia, Z. Dong, L. Yuan, L. Xiao-Yu and C. Xing, J. Mol. Struct., 2004, 692, 71.

48 R. I. Freshney, Culture of animal cells: A manual of basic technique, Wiley-Liss, NY, 5th edn, 1987, p. 200.

49 R. W. Masters, Animal cell culture: Cytotoxicity and viability assays, 3rd edn, 2000, vol. 23, p. 202.

50 D. Garmann, A. Warnecke, G. V. Kalayda, F. Kratz and U. Jaehde, J. Controlled Release, 2008, 131, 100.

51 Y. C. Sasaki and A. Passaniti, BioTechniques, 1998, 24, 1038. 52 F. Gao, H. Chao, F. Zhou, Y. X. Yuan, B. Peng and L. N. Ji, J. Inorg. Biochem., 2006, 100, 1487.

53 A. A. Holder, S. Swavey and K. J. Brewer, Inorg. Chem., 2004, 43, 303.

54 G. Cervantes, V. Moreno, E. Molins and M. Quiros, Polyhedron, 1998, 17, 3343.

55 C. T. Yang, B. Moubaraki, K. S. J. Murray and J. Vittal, Dalton Trans., 2003, 880.

56 B. K. Singh, P. Mishra and B. S. Garg, Spectrochim. Acta, Part A, 2007, 67, 719.

57 G. B. Deacon, F. Huber and R. J. Phillips, Inorg. Chim. Acta, 1985, 104, 41.

58 R. M. Silverstein, O. G. Bassler and T. C. Morrill, Spectrophotometic Identification of Organic Compounds, Wiley, New York, 1974.

59 C. J. Pouchert and J. Behnke, The Aldrich Library of ${ }^{13} \mathrm{C}$ and ${ }^{1} \mathrm{H}$ FTNMR Spectra, Aldrich Chemical Company, Wisconsin, 1993, vol. I, p. 273.

60 N. S. Sisombath, F. Jalilehvand, A. C. Schell and Q. Wu, Inorg. Chem., 2014, 53, 12459.

61 J. Arpalahti and B. Lippert, Inorg. Chem., 1990, 29, 104.

62 W. Shen, R. D. Schnebeck, E. Freisinger and B. Lippert, Dalton Trans., 2008, 4044.

63 K. Sakai, Y. Konno, N. Takayama and S. Takahashi, Acta Crystallogr., Sect. B: Struct. Sci., Cryst. Eng. Mater., 2004, 60, 255.

64 E. Colacio, R. Cuesta, M. Ghazi, M. A. Huertas, J. M. Moreno and A. Navarrete, Inorg. Chem., 1997, 36, 1652.

65 R. Wysokinśki, K. Hernik, R. Szostak and D. Michalska, Chem. Phys., 2007, 333, 37.

66 F. Dimiza, F. Perdih, V. Tangoulis, I. Turel, D. P. Kessissoglou and G. Psomas, J. Inorg. Biochem., 2011, 105, 476.

67 A. Tarushi, C. P. Raptopoulou, V. Psycharis, A. Terzis, G. Psomas and D. P. Kessissoglou, Bioorg. Med. Chem., 2010, 18, 2678.

68 H. Wu, Y. Zhang, C. Chen, J. Zhang, Y. Bai, F. Shi and X. Wang, New J. Chem., 2014, 38, 3688.

69 A. Dimitrakopoulou, C. Dendrinou-Samara, A. A. Pantazaki, M. Alexiou, E. Nordlander and D. P. Kessissoglou, J. Inorg. Biochem., 2008, 102, 618. 